\title{
Heme as a Target for Therapeutic Interventions
}

\section{OPEN ACCESS}

Edited by:

David Sacerdoti,

University of Padua, Italy

Reviewed by:

Nader G. Abraham,

New York Medical College, USA

Mahin D. Maines,

University of Rochester, USA

Viktória Jeney,

University of Debrecen, Hungary

Leo E. Otterbein,

Beth Israel Deaconess Medical Center

(HMS), USA

*Correspondence:

Stephan Immenschuh

immenschuh.stephan@

mh-hannover.de

In Memoriam:

This review is in memory of Ursula Muller-Eberhard who passed away on

November 15, 2016

Specialty section: This article was submitted to Inflammation Pharmacology,

a section of the journal

Frontiers in Pharmacology

Received: 29 November 2016 Accepted: 07 March 2017

Published: 04 April 2017

Citation:

Immenschuh S, Vijayan V, Janciauskiene S and Gueler F (2017) Heme as a Target for Therapeutic Interventions.

Front. Pharmacol. 8:146. doi: 10.3389/fphar.2017.00146

\author{
Stephan Immenschuh ${ }^{1 *}$, Vijith Vijayan ${ }^{1}$, Sabina Janciauskiene ${ }^{2}$ and Faikah Gueler ${ }^{3}$ \\ ${ }^{1}$ Institute for Transfusion Medicine, Hannover Medical School, Hannover, Germany, ${ }^{2}$ Department of Pulmonology, Hannover \\ Medical School, Hannover, Germany, ${ }^{3}$ Department of Nephrology, Hannover Medical School, Hannover, Germany
}

Heme is a complex of iron and the tetrapyrrole protoporphyrin IX with essential functions in aerobic organisms. Heme is the prosthetic group of hemoproteins such as hemoglobin and myoglobin, which are crucial for reversible oxygen binding and transport. By contrast, high levels of free heme, which may occur in various pathophysiological conditions, are toxic via pro-oxidant, pro-inflammatory and cytotoxic effects. The toxicity of heme plays a major role for the pathogenesis of prototypical hemolytic disorders including sickle cell disease and malaria. Moreover, there is increasing appreciation that detrimental effects of heme may also be critically involved in diseases, which usually are not associated with hemolysis such as severe sepsis and atherosclerosis. In mammalians homeostasis of heme and its potential toxicity are primarily controlled by two physiological systems. First, the scavenger protein hemopexin $(\mathrm{Hx})$ non-covalently binds extracellular free heme with high affinity and attenuates toxicity of heme in plasma. Second, heme oxygenases ( $\mathrm{HOs}$ ), in particular the inducible $\mathrm{HO}$ isozyme, $\mathrm{HO}-1$, can provide antioxidant cytoprotection via enzymatic degradation of intracellular heme. This review summarizes current knowledge on the pathophysiological role of heme for various diseases as demonstrated in experimental animal models and in humans. The functional significance of $\mathrm{Hx}$ and $\mathrm{HOs}$ for the regulation of heme homeostasis is highlighted. Finally, the therapeutic potential of pharmacological strategies that apply $\mathrm{Hx}$ and $\mathrm{HO}-1$ in various clinical settings is discussed.

Keywords: heme, hemopexin, hemolysis, heme toxicity, heme oxygenases, inflammation, inflammatory diseases

\section{INTRODUCTION}

Heme is a ubiquitous molecular complex of iron and the tetrapyrrole protoporphyrin IX. When bound to hemoproteins, heme plays an essential role for numerous biological processes in aerobic organisms, which range from reversible oxygen binding to electron transport of the respiratory chain (Wagener et al., 2003; Hamza and Dailey, 2012). However, despite its well-established physiological functions, heme can be harmful and critically involved in the pathogenesis of various diseases. In pathological conditions, such as hemolysis and tissue damage, large amounts of hemoglobin $(\mathrm{Hb})$, myoglobin and other hemoproteins are released into the circulation (Reeder, 2010; Schaer et al., 2012). Specifically, in hemolytic disorders cell-free $\mathrm{Hb}$ released from damaged red blood cells (RBCs) can rapidly exhaust the binding capacity of the scavenger protein haptoglobin $(\mathrm{Hp})$ that neutralizes the pro-oxidant effects of extracellular $\mathrm{Hb}$ (Schaer et al., 2012). Heme iron in non Hp-bound cell-free $\mathrm{Hb}$ is rapidly oxidized from the $\mathrm{Fe}^{2+}$ to the $\mathrm{Fe}^{3+}$ state and forms met-Hb (also termed oxy-Hb), which then releases free heme 
(Bunn and Jandl, 1968; Hebbel et al., 1988; Balla et al., 1993; Figure 1). After exceeding the binding capacity of the heme scavenger hemopexin $(\mathrm{Hx})$, free heme accumulates in the plasma (Muller-Eberhard and Cleve, 1963; Muller Eberhard, 1970; Tolosano and Altruda, 2002). Free heme may also arise from myoglobin and other hemoproteins released from damaged cells during tissue injury (Figure 1). High concentrations of free heme can be cytotoxic via the formation of reactive oxygen species (ROS) (Kumar and Bandyopadhyay, 2005; Larsen et al., 2012; Roumenina et al., 2016). Moreover, due to the lipophilic structure heme can intercalate with cell membranes resulting in lipid and protein peroxidation or DNA damage (Aft and Mueller, 1983, 1984; Vincent, 1989).

In this review, we will summarize the current understanding of how heme toxicity is involved in the pathogenesis of various clinical conditions and diseases, which include not only classical hemolytic diseases, such as sickle cell disease (SCD) and malaria, but also non-typical hemolytic diseases, such as severe sepsis and atherosclerosis. The roles of heme neutralization via the plasma scavenger protein $\mathrm{Hx}$ and heme-degrading heme oxygenases (HOs) are highlighted. Finally, the therapeutic potential of $\mathrm{Hx}$ and that of HOs is discussed in clinically relevant conditions.

\section{PHYSIOLOGICAL FUNCTIONS OF HEME}

The tetrapyrrole heme (iron protoporphyrin IX) not only serves key physiological functions in mammalians, but also in bacteria and plants. Heme is a prosthetic group in numerous hemoproteins, in which it occurs in its non-covalently or covalently bound form (Ponka, 1999; Wagener et al., 2003; Reeder, 2010; Hamza and Dailey, 2012). For example, heme $b$, which is the most abundant form of heme, is noncovalently bound to the hemoproteins $\mathrm{Hb}$ and myoglobin. Both hemoproteins are of major importance for reversible binding and transport of oxygen (Reeder, 2010). Moreover, covalentlybound heme $c$ in cytochrome $c$ is critical for electron transfer in the mitochondrial respiratory chain (Chance, 1967). Similarly, heme is a functionally important compound in multiple other hemoproteins, such as cytochrome-P450s, soluble guanylate cyclase, cyclooxygenase-2, inducible nitric oxide synthase or NADPH oxidases, all of which are key enzymes for cellular homeostasis (Mense and Zhang, 2006). In addition to its role in hemoproteins, a minor portion of intracellular heme is available as so-called "free" heme, which is considered to be loosely associated to proteins other than hemoproteins (Ponka, 1997; Chiabrando et al., 2014; Soares and Bozza, 2016) and is also known as the labile or non-determined heme pool. As proposed for hepatocytes more than four decades ago, free heme has functional regulatory relevance for cellular metabolic events (Granick et al., 1975). Although available only to a minor extent under normal conditions, free heme is an important signaling molecule for cellular sensing of gases (e.g., oxygen, carbon monoxide or nitric oxide) or regulation of the circadian rhythm (Granick et al., 1975; Mense and Zhang, 2006; Burris, 2008; Girvan and Munro, 2013).
Due to the multiple functions of heme, regulation of intraand extracellular heme homeostasis is of major physiological significance and is tightly controlled at various levels. First of all, enzymatic synthesis and degradation of heme is mediated via a complex system that is controlled by feedback mechanisms in a cell type-specific manner (Abraham et al., 1983; Ponka, 1997; Ryter and Tyrrell, 2000; Wijayanti et al., 2004). Moreover, heme transporters, such as the heme exporters Feline leukemia virus subgroup $\mathrm{C}$ receptor 1a (FLVCR1a) or ATP-binding cassette subfamily G member2 (ABCG2) and the heme importer FLVCR2, mediate shuttling of heme across cellular membranes. Finally, a number of heme binding proteins (HBPs), which are discussed in more detail below, can reversibly bind and release heme to control its intra- and extracellular homeostasis (Muller Eberhard and Nikkilä, 1989; Chiabrando et al., 2014). Comprehensive overviews on the multiple physiological functions of heme have been previously given by other authors (Chance, 1967; Ponka, 1999; Wagener et al., 2003; Mense and Zhang, 2006; Hamza and Dailey, 2012; Girvan and Munro, 2013).

\section{HEME TOXICITY IN VARIOUS CELL TYPES}

Although, heme toxicity applies to all cells and tissues, distinct cell types can be differentially affected by its harmful effects. In RBCs as the major population of heme-containing cells, heme critically affects aging via long-term intercalation and destabilization of membranes (Solar et al., 1991; Rifkind and Nagababu, 2013). Activation of neutrophils by heme leads to oxygen radical production, chemotaxis and the formation of neutrophil extracellular traps (Chen et al., 2014). Importantly, various cell types exhibit different sensitivities to the toxicity of heme. For example, heme causes cell death in cultures of endothelial cells at markedly lower concentrations as compared to macrophages or epithelial cells (Vijayan and Immenschuh, unpublished observations) suggesting that various modes of auto-protection against heme toxicity are operative in divergent types of cells. Moreover, in distinct pathophysiological settings, cells may exhibit context-specific spatial and temporal regulatory patterns of adaptation. Herein, we focus on heme toxicity in endothelial cell and monocyte/macrophage models (Figure 1).

\section{Endothelial Cells}

The endothelium, in particular the vascular endothelium, has important homeostatic functions and is involved in the pathogenesis of various diseases including inflammatory cardiovascular disorders (Pober et al., 2009). In hemolysis the vascular endothelium may encounter increased concentrations of heme, which can be as high as $100 \mu \mathrm{M}$ (Muller-Eberhard et al., 1968; Balla et al., 1993; Wagener et al., 2003). Autoprotection of the endothelium against heme toxicity is of critical importance under hemolytic conditions, because heme can sensitize cell cultures of endothelial cells to prooxidant damage by granulocytes or toxic ROS (Balla et al., 1991). Moreover, heme induces inflammatory activation of endothelial cells in vitro and in vivo as indicated by the up-regulation of inducible adhesion molecules including vascular cell adhesion molecule (VCAM)-1 or intercellular cell adhesion molecule 


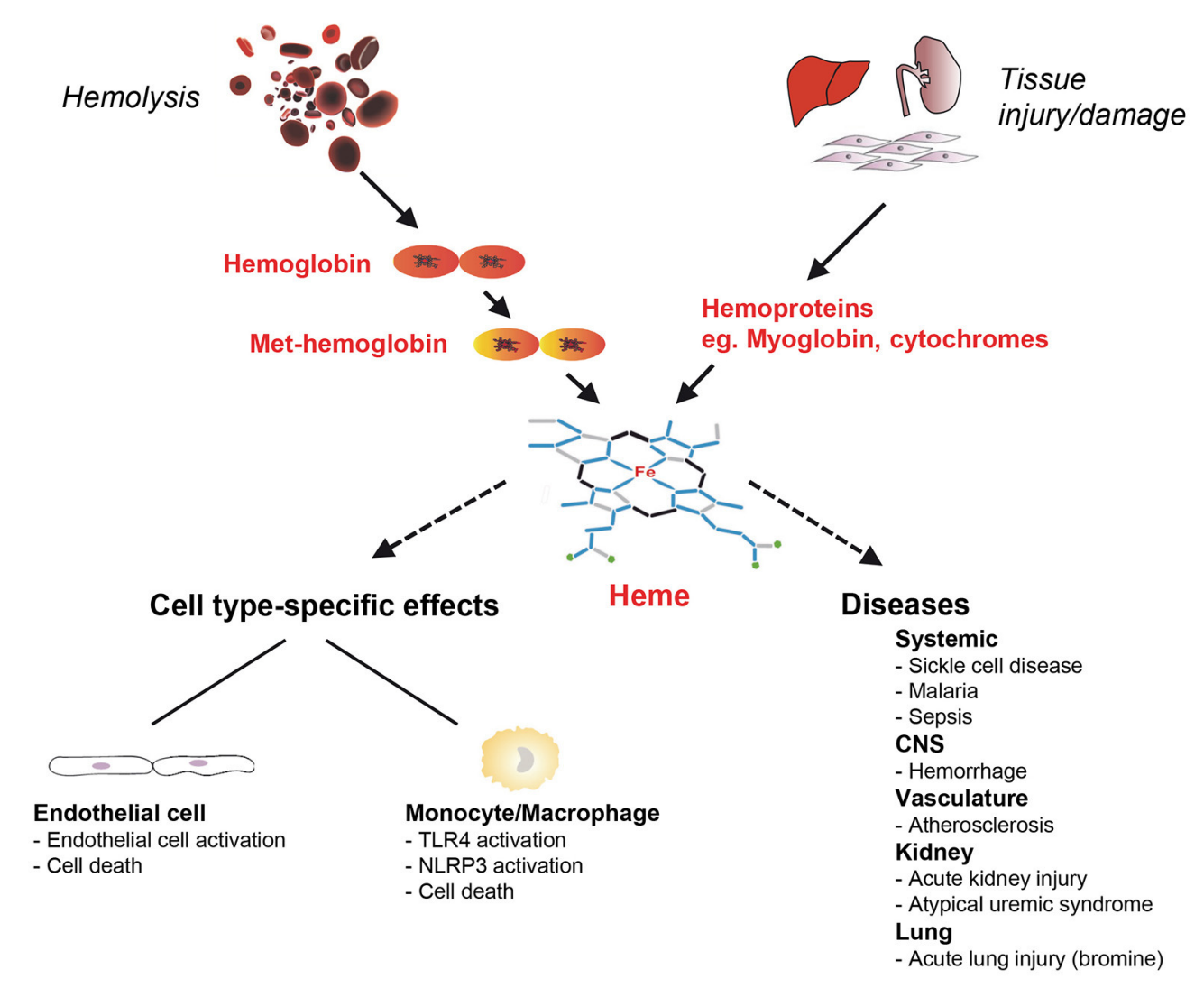

FIGURE 1 | Schematic on cell-type specific effects of heme toxicity and its role in the pathogenesis of diseases. Free heme can arise in hemolysis from cell-free hemoglobin $(\mathrm{Hb})$ oxidized to Met- $\mathrm{Hb}$ and in tissue damage and injury from intracellular hemoproteins that are released from cells such as myoglobin. Heme has pro-oxidant, pro-inflammatory and cytotoxic effects and can cause cell type-specific effects in endothelial cells and monocytes/macrophages. Heme is involved in the pathogenesis of various hemolytic diseases including sickle cell disease (SCD) and malaria, but also in disorders that are not typically associated with hemolysis. CNS, central nervous system; NLRP3, nucleotide-binding domain and leucine-rich repeat pyrin 3 containing; TLR, toll-like receptor.

(ICAM)-1 (Wagener et al., 1997, 2001) as well as release of von Willebrand factor and P-selectin from Weibel-Palade bodies (Belcher et al., 2014; Figure 1). It is also important to note that auto-protection of endothelial cells against heme toxicity is markedly impaired in murine and human genetic deficiency of HO-1, which is the inducible isoform of the heme-degrading enzyme HO (discussed in more detail below) (Tenhunen et al., 1968; Abraham et al., 1988; Maines, 1997). In murine and human HO-1 deficiency the endothelium is afflicted by major pro-oxidant damage and detachment from glomerular basal membranes (Poss and Tonegawa, 1997a; Yachie et al., 1999; True et al., 2007). Remarkably, endothelial HO1 gene expression is inversely linked with platelet endothelial cell adhesion molecule (PECAM)-1, a key endothelial surface receptor, suggesting a specific interrelation between these two proteins in the endothelium (Saragih et al., 2014).

\section{Macrophages/Monocytes}

Macrophages are key cells of the immune system controlling homeostasis of immunological regulation, host defense and wound healing (Mosser and Edwards, 2008). Macrophages are resistant to relatively high concentrations of heme in comparison to endothelial cells. A major function of spleen and liver tissue macrophages is the elimination of circulating senescent RBCs. Thus, it is not surprising that these cells exhibit constitutive high expression of HO-1 in vivo to protect against heme toxicity (Bissell et al., 1972; Immenschuh et al., 1999, 2003). Interestingly, differentiation of liver and spleen tissue macrophages is modulated via a heme-dependent pathway that involves the nuclear heme-regulated protein BTB domain and CNC homolog 1 (Bach1) (Haldar et al., 2014). Major relevance of macrophages for heme recycling and iron homeostasis has also been demonstrated in HO-1 knockout mice, that exhibit reduced numbers and function of erythrophagocytosing macrophages (Kovtunovych et al., 2010). It is important to note that heme, but not its analogs or precursors, activates murine macrophages via toll-like receptor (TLR)-4 (Figueiredo et al., 2007). Moreover, cell-free $\mathrm{Hb}$ and its derivative heme, which can arise from damaged RBCs, synergistically up-regulated TLRdependent pro-inflammatory responses in primary mouse bonemarrow derived macrophages (Lin et al., 2010). The underlying mechanistic details on the interactions of heme with TLRs and the potential intracellular signaling cascades that may mediate these functional interactions are under investigation (Dutra and 


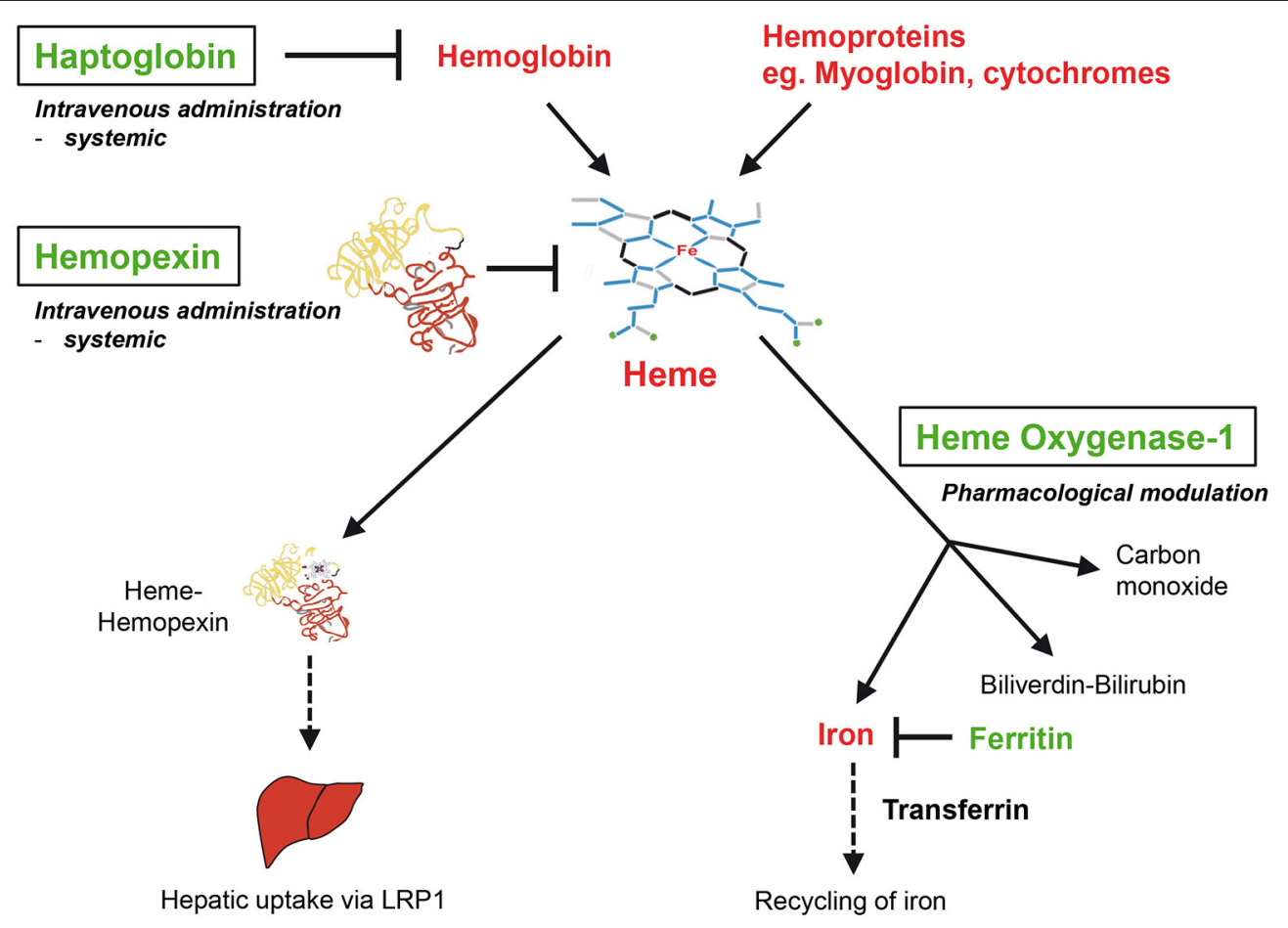

FIGURE 2 | Therapeutic interventions for the neutralization of heme. The antioxidant scavenger proteins haptoglobin ( $\mathrm{Hp})$ and hemopexin ( $\mathrm{Hx}$ ) bind and neutralize extracellular $\mathrm{Hb}$ and free heme in plasma, respectively. $\mathrm{HO}-1$ is the inducible isoform of $\mathrm{HOs}$, which enzymatically degrade intracellular heme to produce iron, carbon monoxide and biliverdin, which is converted into bilirubin by biliverdin reductase. Hx and Hp may be applied as a potential heme-neutralizing therapy via systemic intravenous administration. Potential therapies of $\mathrm{HO}-1$ may be performed via targeted pharmacological induction. LRP1, low density lipoprotein receptor-related protein 1.

Bozza, 2014; Soares and Bozza, 2016). More recently, heme has also been shown to activate the nucleotide-binding domain and leucine-rich repeat pyrin 3 containing (NLRP3) inflammasome in murine macrophages in vivo and in vitro (Dutra et al., 2014; Figure 1).

In conclusion, various cell types are differentially affected by the toxicity of heme and play distinct roles for the control of local and systemic heme homeostasis in physiological and pathophysiological conditions.

\section{ROLE OF HEME IN THE PATHOGENESIS OF DISEASES}

A growing number of reports has demonstrated a critical role of heme toxicity in the pathogenesis of various diseases (Muller Eberhard and Nikkilä, 1989; Ryter and Tyrrell, 2000; Wijayanti et al., 2004; Kumar and Bandyopadhyay, 2005). In severe hemolysis or tissue injury excess amounts of extracellular $\mathrm{Hb}$, myoglobin and free heme overwhelm the binding capacity of the plasma scavengers $\mathrm{Hp}$ and $\mathrm{Hx}$ and cause systemic or local hemedependent pathologies (Figures 1, 2). Besides, heme can have indirect toxic effects in the pathogenesis of atherosclerosis (Nagy et al., 2010) or irritant gas-induced acute lung injury (Aggarwal et al., 2016). Heme may also act as a secondary hit that causes disease manifestation of a preexisting clinical risk constellation
(Frimat et al., 2013). In this section, different roles of heme for the pathophysiology of experimental animal models and human disorders are discussed.

\section{Animal Models of Human Diseases Hemolytic Diseases: SCD and Malaria}

Important findings on the pathogenic potential of heme have been reported in experimental mouse models of SCD and malaria. Although of different origin, pathologies in both disorders are primarily linked to large amounts of hemoproteins released from damaged RBCs. SCD is a genetic disorder caused by an amino acid exchange in the $\mathrm{Hb} \beta$-chain, which leads to the production of abnormally shaped sickle cells prone to intravascular hemolysis (Ingram, 1957). Experimental SCD mouse models seem to exhibit typical signs of vascular inflammation (Belcher et al., 2003). Furthermore, as indicated by leukocyte infiltration and thrombosis, heme toxicity is likely associated with phenotypical alterations of the vascular endothelium (Belcher et al., 2014; Keleku-Lukwete et al., 2015). Independently, heme was responsible for pro-inflammatory M1 polarization of macrophages (Vinchi et al., 2016), formation of neutrophil extracellular traps (Chen et al., 2014), and triggering of acute chest syndrome (Ghosh et al., 2013) in SCD mice. In malaria, which is a protozoan disease, hemolysis is caused by infection with and replication of Plasmodium in RBCs (Miller 
et al., 2002). In mouse models of experimental malaria release of extracellular $\mathrm{Hb}$ and heme from damaged RBCs also had major pro-oxidant and pro-inflammatory effects. Hemolysisderived heme was directly involved in inflammatory pathologies of experimental murine cerebral and non-cerebral malaria (Pamplona et al., 2007; Seixas et al., 2009).

\section{Central Nervous System (CNS) Hemorrhage}

CNS hemorrhage occurring spontaneously, like in subarachnoid hemorrhage and stroke or because of traumatic injuries, can be closely associated with the toxicity of cell-free $\mathrm{Hb}$ and heme. In a feline model exposure to cell-free $\mathrm{Hb}$ caused marked prooxidant damage of nerve cells in vivo, which was primarily due to lipid peroxidation (Sadrzadeh et al., 1987). Similar findings have been reported in an experimental rabbit model of preterm pup intraventricular hemorrhage, in which $\mathrm{Hb}$ and heme led to inflammatory changes and cell death in affected tissues (Gram et al., 2014). Furthermore, heme toxicity played an important role in the pathogenesis of brain injury in a mouse model of intracerebral injection of cell-free $\mathrm{Hb}$ (Ma et al., 2016).

\section{Sepsis}

Sepsis and its more complicated manifestations, severe sepsis and septic shock, are characterized by an excessive systemic inflammatory response to various acute injuries (Bone, 1991; Gotts and Matthay, 2016). The pathophysiology of this complex disorder is not understood in detail (Angus and van der Poll, 2013). Recently, cell-free $\mathrm{Hb}$ and heme have been shown to be involved in the pathogenesis of severe sepsis in a mouse model of cecal ligation and puncture polymicrobial sepsis in vivo (Larsen et al., 2010). Similarly, pro-inflammatory effects of extracellular $\mathrm{Hb}$ and heme from degraded erythrocytes worsened the survival rate in an experimental rat model of $E$. coli-mediated sepsis (Griffiths et al., 1995).

\section{Transfusion of RBCs}

Numerous reports have associated transfusions of packed RBCs after prolonged storage with increased morbidity and mortality in trauma-induced hemorrhage among other conditions. Detrimental effects of stored RBCs have been associated with the so-called "storage lesion," which is characterized by RBC alterations including loss of metabolites, decreased cell volume with accompanying formation of echinocytes and release of free $\mathrm{Hb}$ due to hemolysis (Lelubre et al., 2009). The storage lesion has been directly linked to the toxicity of cell-free $\mathrm{Hb}$ and heme in a model of guinea pigs, in which transfusion of senescent RBCs was more harmful if compared with fresh RBC preparations (Baek et al., 2012). Similarly, others have demonstrated that heme toxicity due to RBC storage lesion markedly aggravated the outcome in two independent mouse models of trauma-induced hemorrhage (Stapley et al., 2015; Graw et al., 2016). Finally, transfusion of senescent RBCs aggravated inflammation and worsened outcome in a canine model of infectious pneumonia (Wang et al., 2012a).

\section{Disorders in Kidney, Heart, and Lung}

Heme toxicity is also involved in the pathogenesis of diseases in solid organs such as kidney. For example, experimental rhabdomyolysis, in which large amounts of intracellular hemoproteins such as myoglobin are released, cause hemedependent acute kidney injury (AKI) (Nath et al., 1992). Moreover, the detrimental pro-oxidant effects of hemoproteins were shown to be directly involved in kidney cell damage in vitro and in vivo (Nath et al., 1995). More recent studies in mouse models have extended these earlier findings by demonstrating that the heme degradation product iron and the iron-sequestering protein ferritin are critically associated with heme-dependent renal injury (Zarjou et al., 2013; Bolisetty et al., 2015). Comprehensive overviews on the pathophysiology of heme toxicity in kidney diseases have been previously given (Tracz et al., 2007; Lever et al., 2016). As to cardiac disorders increased levels of heme seem to aggravate ischemia-reperfusion injury in experimental murine heart disease. This novel finding suggests an important role for heme in the pathogenesis of ischemic cardiomyopathy (Sawicki et al., 2015). Remarkably, heme toxicity was also critically involved in acute lung injury due to bromine inhalation in a mouse model (Aggarwal et al., 2016).

\section{Human Diseases}

Mouse models are useful to explore basic pathophysiological disease mechanisms and to investigate novel therapeutic interventions. However, species-specific differences in fundamental regulatory systems between mouse and human have been pointed out, e.g., for the immune system (Mestas and Hughes, 2004), indicating that experimental findings in animal models may not always be translatable into clinical applications. It is also important to note that human disorders are in general more complex in comparison to mouse disease models, which are frequently caused by single mechanisms (Warren et al., 2015). Major discrepancies in various inflammatory conditions of mouse and human have been reported for genomic responses and are controversially discussed (Seok et al., 2013).

\section{SCD and Malaria}

Patients with hemolytic disorders such as SCD exhibit increased serum levels of heme (Muller-Eberhard et al., 1968) and develop acute and/or chronic manifestations of heme toxicity (Nath and Katusic, 2012). Remarkably, in SCD patients heme-carrying RBC membrane microparticles were responsible for endothelial cell damage (Camus et al., 2015) and heme specifically affected $\mathrm{T}$ cell polarization via interaction with CD16+ monocytes (Zhong et al., 2014). A direct pathogenic role for heme toxicity has also been demonstrated in human malaria. Heme markedly down-regulated prostaglandin and transforming growth factor- $\beta$ production in malaria (Andrade et al., 2010). Moreover, increased concentrations of heme were associated with higher susceptibility to malaria (Mendonca et al., 2012) and disease outcome was linked with systemic levels of extracellular heme in these patients (Elphinstone et al., 2016).

\section{Sepsis}

Similar to findings in mouse models, heme appears to play a role in the pathogenesis of severe sepsis in humans as indicated by lower serum levels of $\mathrm{Hx}$, which decrease due to increased levels of heme (Larsen et al., 2010). Accordingly, poor outcome in sepsis 
patients has been associated with decreased serum levels of $\mathrm{Hp}$ and Hx (Janz et al., 2013; Lin et al., 2015). In the context of sepsis it is important to note that mice exhibit markedly higher tolerance to endotoxin relative to humans (Schaedler and Dubos, 1961).

\section{Transfusion of Packed RBCs}

Transfusion of packed RBCs after prolonged storage has been associated with an increased risk of death in critically ill patients (Wang et al., 2012b). Therefore, the potential risk of transfusing senescent RBCs needs to be addressed by prospective controlled studies to clarify this issue in more detail.

\section{Cardiac Diseases (Atherosclerosis, Ischemic Cardiomyopathy, and Heart Failure)}

Hemolysis-derived heme may be indirectly involved in the pathogenesis of atherosclerosis. The oxidation of lipoproteins and other plasma proteins by pro-oxidant iron from cell-free $\mathrm{Hb}$ and heme plays an important pathophysiological role for the complex sequence of vascular events that cause atherosclerosis (Jeney et al., 2002, 2014; Nagy et al., 2010). In clinical studies on chronic ischemic cardiomyopathy increased levels of heme have been observed in cardiac biopsies from patients with failing hearts (Sawicki et al., 2015). Independently, up-regulation of heme levels have been associated with a worse clinical outcome in patients with heart failure (Khechaduri et al., 2013). Interestingly, heme toxicity has recently been implicated in the pathogenesis of heart failure via affecting the contractile function of cardiomyocytes (Alvarado et al., 2015).

\section{Atypical Hemolytic Uremic Syndrome}

A recent clinical study of patients with atypical hemolytic uremic syndrome (a rare thrombotic microangiopathy primarily observed in the kidney) identified heme as a critical secondary hit that triggers the clinical manifestation of this disorder. Specifically, heme in plasma from patients with atypical hemolytic uremic syndrome activated the alternative pathway of the complement cascade, which in turn caused endothelial cell activation (Frimat et al., 2013). These findings suggest that heme may have similar effects in the pathophysiology of other vascular inflammatory diseases.

\section{Diagnostic Tests for Determining Free Heme Levels in Plasma and Tissues}

A major hurdle for a better understanding of heme toxicity in clinical practice is the lack of a reliable diagnostic test for determining levels of free heme in plasma and tissue biopsies. Currently, the severity of hemolysis and the potential toxicity of heme can only be indirectly estimated via determining plasma concentrations of $\mathrm{Hp}$ and $\mathrm{Hx}$, both of which inversely correlate with increased levels of cell-free $\mathrm{Hb}$ and free heme in severe hemolysis (Muller-Eberhard et al., 1968). Thus, a diagnostic test for determining heme concentrations in biological fluids and tissues is urgently needed.

In conclusion, experimental animal models of human disease and studies in human disorders confirm the pertinent pathophysiological role of heme toxicity; however, the appropriate test systems for detection of free heme are still missing.

\section{PROTECTION AGAINST HEME TOXICITY VIA HEMOPEXIN AND THE HEME OXYGENASE SYSTEM - ITS THERAPEUTIC POTENTIAL}

\section{Regulation of Physiological Heme Homeostasis by Hemopexin $(\mathrm{Hx})$ and Heme Oxygenases (HOs)}

In mammalians heme homeostasis is primarily controlled by two regulatory systems. Firstly, the plasma scavenger protein $\mathrm{Hx}$ neutralizes and eliminates excess free heme from the circulation. Secondly, intracellular heme is primarily enzymatically degraded via the heme-catabolizing HOs, in particular by its inducible isoform HO- 1 .

\section{Hemopexin $(\mathrm{Hx})$}

The plasma protein $\mathrm{Hx}$ binds non-covalently heme with the highest affinity of any known protein $\left(\mathrm{K}_{\mathrm{D}} 10^{-14}\right)$ (MullerEberhard and Cleve, 1963; Muller Eberhard, 1970; Tolosano and Altruda, 2002) via its characteristic heme-binding pocket (Paoli et al., 1999). The major function of $\mathrm{Hx}$ appears to be neutralization and scavenging of excess free heme from the circulation. Up-take of heme-Hx complexes in the liver (Potter et al., 1993) is mediated via the scavenger receptor low-density lipoprotein receptor-related protein-1 (LRP1, synonymous with CD91) (Hvidberg et al., 2005; Vercellotti et al., 2016). Hx belongs to the acute-phase reactants, which include a number of plasma proteins such as C-reactive protein, $\alpha 2$-macroglobulin and $\alpha 1$ antitrypsin that are up-regulated in the liver as part of a systemic inflammatory response (Heinrich et al., 1990; Baumann and Gauldie, 1994). Hx is induced during the acute-phase response in rodents, but not in human, which might be due to evolutionary differences in rodent and human Hx gene promoters (Heinrich et al., 1990; Poli et al., 1990; Immenschuh et al., 1994). This species-specific difference of $\mathrm{Hx}$ gene regulation in rodents and humans correlates with the recently reported findings that $\mathrm{Hx}$ is up-regulated during sepsis in mice, but down-regulated in humans (Lin et al., 2015). Hx knockout mice exhibit a normal phenotype in non-challenged conditions, but are afflicted with heme-mediated renal and hepatic damage in conditions of experimental hemolysis (Tolosano et al., 1999; Vinchi et al., 2008). Remarkably, heme-mediated pathologies are aggravated in $\mathrm{Hx} / \mathrm{Hp}$ double knockout mice (Tolosano et al., 2002) suggesting that these two plasma proteins represent a sequential protection system against the detrimental effects of hemolysis (Deuel et al., 2015; Smith and McCulloh, 2015; Figure 2).

\section{Other Heme Binding Proteins (HBPs)}

In addition to $\mathrm{Hx}$, other HBPs are likely to be involved in the regulation of systemic extracellular and also intracellular homeostasis of heme and may counteract its pro-oxidant effects. The functional significance of most known HBPs for neutralization and transport of heme is only incompletely 
understood. However, it has been pointed out that the specific heme-protein interactions of a given HBP determine its protective potential against the pro-oxidant effects of heme, respectively (Vincent et al., 1988; Vincent, 1989). Another extracellular HBP with major physiological significance is albumin, which binds heme with markedly lower affinity than $\mathrm{Hx}\left(\mathrm{K}_{\mathrm{D}} 1.2 \times 10^{-8}\right)$ (Little and Neilands, 1960), but exhibits markedly higher plasma concentrations relative to $\mathrm{Hx}$ (Adams and Berman, 1980) (Table 1). Other known extracellular plasma HBPs are $\alpha 1$-microglobulin (Allhorn et al., 2002) and $\alpha 1$ antitrypsin (Karnaukhova et al., 2012) (Table 1). Intracellular binding of heme by HBPs may not only protect against its potential pro-oxidant toxicity, but may be also involved in trafficking of heme between different cell compartments (Muller Eberhard and Nikkilä, 1989; Liem et al., 1994; Yuan et al., 2016). Thus, the specific functional roles of intracellular candidate HBPs in mammalians such as glutathioneS-transferases, heme-binding protein/ liver fatty-acid binding protein, heme-binding protein 23/peroxiredoxin 1, p22 heme binding protein and glyceraldehyde-3-phosphate dehydrogenase (Harvey and Beutler, 1982; Vincent and Muller Eberhard, 1985; Iwahara et al., 1995; Taketani et al., 1998; Chakravarti et al., 2010) need to be investigated in more detail (Table 1).

\section{Heme Oxygenases (HOs)}

Enzymatic degradation of intracellular heme is primarily mediated via the HO system independent of P450s (Tenhunen et al., 1968; Maines and Kappas, 1974; Maines, 1997). The HO reaction has three major products: the signaling gas carbon monoxide (CO), iron and biliverdin, which is subsequently converted into bilirubin by biliverdin reductase (Kutty and Maines, 1981; Figure 2). Two genetically distinct isoforms of $\mathrm{HO}$ are known. HO-2 represents the constitutive non-inducible isoform and is primarily expressed in brain and testes (Trakshel et al., 1986). By contrast, the inducible $\mathrm{HO}$ isoform, HO-1, is expressed in almost all cells and tissues, and is highly upregulated by heme or other stress stimuli to provide protection against oxidative damage and apoptosis (Maines, 1997; Ryter et al., 2006). The cytoprotective functions of HO-1 are directly linked with that of the iron-sequestering protein ferritin, which is co-ordinately up-regulated with $\mathrm{HO}-1$ and neutralizes the pro-oxidant effects of the HO product iron (Balla et al., 1992; Figure 2). Importantly, genetic deficiency in mouse models and/or genetic deficiency and functional defects of HO-1 in humans are associated with major pro-oxidant and proinflammatory pathologies and with disturbed iron metabolism (Poss and Tonegawa, 1997a,b; Yachie et al., 1999; Kapturczak et al., 2004; Greil et al., 2016). In contrast, deficiency of the HO-2 gene in mice does not cause major heme-dependent pathologies (Poss et al., 1995) suggesting that HO-1 might be the more critical $\mathrm{HO}$ isozyme for counter-acting heme toxicity (Wagener et al., 2003; Kumar and Bandyopadhyay, 2005; Gozzelino et al., 2010). Studies in a conditional HO-1 knockout mouse model with targeted deletion in myeloid cells revealed a critical role of $\mathrm{HO}-1$ for the regulation of innate immunity (Tzima et al., 2009). It is also interesting to point out that patterns of mouse and human $\mathrm{HO}-1$ gene expression are differentially regulated in a species-specific manner (Sikorski et al., 2004). For example, HO-1 gene expression is upregulated by lipopolysaccharide in mouse macrophages, but down-regulated in human macrophages (Miyazaki et al., 2010; Dorresteijn et al., 2015). Notably, the proximal promoter region of the human HO-1 gene, but not that of the mouse, contains a GT-microsatellite polymorphism, which may be responsible for interspecies-specific regulatory differences (Yamada et al., 2000). Finally, higher inducibility of the human HO-1 gene by oxidative stress has been associated with protection against cardiovascular disorders (Exner et al., 2004; Pechlaner et al., 2015) and against acute chest syndrome in SCD (Bean et al., 2012). Comprehensive overviews on the multiple roles of the $\mathrm{HO}$ system in health and disease have previously been given (Maines, 1997; Immenschuh and Ramadori, 2000; Abraham and Kappas, 2005; Ryter et al., 2006).

\section{Applications of Hemopexin and Heme Oxygenases for Potential Therapeutic Interventions}

Various therapeutic strategies that may apply specific neutralization of heme toxicity via either $\mathrm{Hx}$ or $\mathrm{HOs}$ are conceivable in clinical settings and will be discussed in the following.

\section{Hemopexin}

Hx protects against heme toxicity not only in animal models of hemolytic disorders such as SCD and malaria (Ghosh et al., 2013; Belcher et al., 2014), but also in other diseases, which are not typically associated with hemolysis such as sepsis (Larsen et al., 2010), cardiac disease (Vinchi et al., 2013) and bromine-induced acute lung injury (Aggarwal et al., 2016) (Table 2). It is plausible that the salutary effects of $\mathrm{Hx}$ described in animal disease models are translatable into the clinic. Hx might also have a prophylactic potential in clinical risk constellations, in which heme triggers overt disease manifestation. For example, pretreatment with $\mathrm{Hx}$ before transfusion of senescent RBCs improved the outcome in different mouse models of trauma-induced hemorrhage via neutralization of heme (Stapley et al., 2015; Graw et al., 2016). The role of Hx administration as a preventive intervention is also supported by findings of others (Tolosano et al., 2010). Hence, it is conceivable that patients that might benefit from prophylactic Hx treatment are those with comorbidities (i.e., diabetes mellitus, hypertension and older age) and an increased risk for AKI, with a high likelihood for the need of RBC transfusion during major surgery. Notably, in Japan $\mathrm{Hp}$ has been approved for medical indications, in which renal protection is required such as in massive transfusion or thermal injury (Schaer et al., 2012). Due to the known protective effects of $\mathrm{Hx}$ and $\mathrm{Hp}$ in hemolysis it is reasonable to assume that combined treatment with these two proteins may provide a synergistic protection in clinical settings of severe hemolysis (Schaer et al., 2014; Deuel et al., 2015; Graw et al., 2016).

\section{Pharmacological applications of $\mathrm{Hx}$}

Intravenous administration of $\mathrm{Hx}$ appears to be a straightforward approach to neutralize free heme toxicity in hemolytic 
TABLE 1 | Heme binding proteins (HBPs) in mammalians.

\begin{tabular}{|c|c|c|c|}
\hline Heme binding protein & Concentration & $\mathbf{K}_{\mathbf{D}}$ & References \\
\hline \multicolumn{4}{|l|}{ EXTRACELLULAR } \\
\hline Hemopexin & $0.6-1.2 \mathrm{~g} / \mathrm{L}$ & $1 \times 10^{-14}$ & Muller-Eberhard and Cleve, 1963; Muller Eberhard, 1970 \\
\hline Albumin (human) & $35-53 \mathrm{~g} / \mathrm{L}$ & $1.2 \times 10^{-8}$ & Little and Neilands, 1960; Adams and Berman, 1980 \\
\hline a1-Microglobulin & $0.03 \mathrm{~g} / \mathrm{L}$ & $1 \times 10^{-6}$ & Allhorn et al., 2002 \\
\hline$\alpha 1-$ Antitrypsin & $1.3-2.5 \mathrm{~g} / \mathrm{L}$ & $2 \times 10^{-8}$ & Karnaukhova et al., 2012 \\
\hline \multicolumn{4}{|l|}{ INTRACELLULAR } \\
\hline Glutathione-S transferases & $3-5 \%$ of total protein (liver) & $1 \times 10^{-7}$ & Harvey and Beutler, 1982 \\
\hline Heme binding protein/Liver fatty acid binding protein & $3-5 \%$ of total protein (liver) & $2 \times 10^{-7}$ & Vincent and Muller Eberhard, 1985 \\
\hline Heme binding protein 23/peroxiredoxin 1 & $0.1 \%$ of total protein (liver) & $5.5 \times 10^{-8}$ & Iwahara et al., 1995 \\
\hline p22 heme-binding protein & n. d. & $2.5 \times 10^{-8}$ & Taketani et al., 1998 \\
\hline Glyceraldehyde-3-phosphate dehydrogenase & $10 \%$ of total protein (skeletal muscle) & n. d. & Chakravarti et al., 2010 \\
\hline
\end{tabular}

TABLE 2 | Hemopexin $(\mathrm{Hx})$ as a therapy against heme toxicity in experimental disease models.

\begin{tabular}{|c|c|c|c|}
\hline Experimental disease model & Therapeutic strategy & Protective effect & References \\
\hline $\begin{array}{l}\text { Heme-induced acute chest syndrome in } \\
\text { SCD mouse (C57BL/6) }\end{array}$ & $\begin{array}{l}\text { Injection of single dose of recombinant human } \\
\mathrm{Hx}(1 \mathrm{mg} / \mathrm{mouse})\end{array}$ & $\begin{array}{l}\text { Heme clearance from plasma } \\
\text { Prevention of acute lung injury } \\
\text { Reduced mortality } \\
\text { Hx treatment at the time of haemolytic crisis } \\
\text { onset prevents respiratory failure }\end{array}$ & Ghosh et al., 2013 \\
\hline $\begin{array}{l}\text { Cecal-ligation puncture induced severe } \\
\text { sepsis in mouse (BALB/c) }\end{array}$ & $\begin{array}{l}\text { Injection of multiple doses of rabbit } \mathrm{Hx} \text { (50 } \\
\mathrm{mg} / \mathrm{kg} \text { ) }\end{array}$ & $\begin{array}{l}\text { Reduced tissue damage. } \\
\text { Reduced mortality }\end{array}$ & Larsen et al., 2010 \\
\hline $\begin{array}{l}\text { SCD mouse }(\mathrm{C} 57 \mathrm{BL} / 6) / \beta \text {-thalassemia } \\
\text { mouse }(\mathrm{C} 57 \mathrm{BL} / 6)\end{array}$ & $\begin{array}{l}\text { Injection of multiple doses of } \mathrm{Hx}(0.7 \\
\mathrm{mg} / \mathrm{mouse})\end{array}$ & $\begin{array}{l}\text { Attenuation of endothelial cell activation } \\
\text { Decreased iron accumulation in the heart } \\
\text { Normalized blood pressure and improved } \\
\text { cardiac function }\end{array}$ & Vinchi et al., 2013 \\
\hline SCD mouse (NY1DD (C57BL/6)) & $\begin{array}{l}\text { Liver-targeted mouse Hx gene delivery by } \\
\text { Sleeping Beauty transposase system }\end{array}$ & $\begin{array}{l}\text { Increased expression of } \mathrm{Nrf} 2 \text { and } \mathrm{HO}-1 \\
\text { Reduced heme induced microvascular stasis }\end{array}$ & Vercellotti et al., 2016 \\
\hline $\begin{array}{l}\text { Resuscitation after hemorrhagic shock in } \\
\text { mouse (C57BL/6) }\end{array}$ & Injection of single dose of $\mathrm{Hx}$ (7.5 mg/mouse) & $\begin{array}{l}\text { Reduced circulating free heme levels } \\
\text { Reduced expression of pro-inflammatory } \\
\text { cytokine IL-6 } \\
\text { Reduced mortality }\end{array}$ & Graw et al., 2016 \\
\hline $\begin{array}{l}\text { Resuscitation after trauma-induced } \\
\text { hemorrhage in mouse (C57BL/6) }\end{array}$ & Injection of single dose of $\mathrm{Hx}$ ( $0.5 \mathrm{mg} /$ mouse) & $\begin{array}{l}\text { Decreased BAL protein levels } \\
\text { Reduced mortality }\end{array}$ & Stapley et al., 2015 \\
\hline
\end{tabular}

$B A L$, bronchoalveolar lavage; $S C D$, sickle cell disease.

conditions. Thus, Hx may be applied as a human blood-derived product, similar to other plasma proteins, such as albumin, $\alpha 1$-antitrypsin or immunoglobulins, which are well-established therapies. Alternatively, it is also feasible that $\mathrm{Hx}$ might become available as a recombinant protein (Satoh et al., 1994; Hada et al., 2014). Potential side effects of Hx treatment may be caused by its known protease activity, which has been associated with inhibition of leukocyte chemotaxis and increased mortality in a mouse model (Cheung et al., 1999; Bakker et al., 2005; Spiller et al., 2011). A more recent study, however, indicated that the protease activity of $\mathrm{Hx}$ might not be of major clinical relevance (Lin et al., 2016).

In conclusion, the plasma protein $\mathrm{Hx}$ has major therapeutic potential for the neutralization of heme toxicity in various clinically relevant conditions.

\section{Heme Oxygenase-1}

HO-1 has been shown to provide specific protection against heme toxicity in different animal models including mouse models of
SCD (Belcher et al., 2006, 2010), malaria (Pamplona et al., 2007; Seixas et al., 2009) and rhabdomyolysis (Wei et al., 2011). In particular, the beneficial effects of $\mathrm{HO}-1$ have been demonstrated in mouse models, in which $\mathrm{HO}-1$ has been either genetically deleted or overexpressed (Table 3). However, when HO-1 is targeted for therapeutic purposes, a major challenge is that HO-1 appears to be only protective when up-regulated before onset of an experimental injury. The latter has been confirmed in rodent models of experimental pancreatitis and colitis suggesting that HO-1 might be a primary option for prophylactic interventions (Nakamichi et al., 2005; Paul et al., 2005). Comprehensive overviews on challenges with potential translational applications of HO-1 in the clinic have recently been given for renal diseases (Lever et al., 2016).

\section{Pharmacological approaches that target HO-1}

In contrast to the straightforward therapeutic application of $\mathrm{Hx}$ as systemically administered intravenous drug, potential interventions with HO-1 appear to be more complex. Multiple 
TABLE 3 | Heme oxygenase (HO)-1 as a therapy against heme toxicity in experimental disease models.

\begin{tabular}{|c|c|c|c|}
\hline Experimental disease model & Therapeutic strategy & Specific protective effect & References \\
\hline $\begin{array}{l}\text { Glycerol-induced acute kidney injury in rat } \\
\text { (Sprague Dawley) }\end{array}$ & $\begin{array}{l}\text { Preconditioning of } \mathrm{HO}-1 \text { using } \\
\text { hemoglobin ( } 30 \mathrm{mg} / 100 \mathrm{~g} \text { body } \\
\text { weight) } 20 \mathrm{~h} \text { prior to injection with } \\
\text { glycerol }\end{array}$ & $\begin{array}{l}\text { Protection from kidney failure } \\
\text { Reduced mortality }\end{array}$ & Nath et al., 1992 \\
\hline $\begin{array}{l}\text { Glycerol-induced acute kidney injury in mouse } \\
\text { (C57BL/6) }\end{array}$ & $\begin{array}{l}\text { Preconditioning of } \mathrm{HO}-1 \text { using } \\
\mathrm{GM}-\mathrm{CSF} \text { ( } 200 \mathrm{mg} / \mathrm{kg} \text { body weight) for } \\
5 \text { consecutive days prior to injection } \\
\text { with glycerol }\end{array}$ & $\begin{array}{l}\text { Reduced blood urea nitrogen levels } \\
\text { Reduced tissue damage } \\
\text { Reduced mortality }\end{array}$ & Wei et al., 2011 \\
\hline Exposure to bromine gas in mouse (C57BL/6) & $\begin{array}{l}\text { Genetic overexpression of human } \\
\mathrm{HO}-1 \text { using (BAC) }\end{array}$ & $\begin{array}{l}\text { Attenuated bromine-induced heme levels } \\
\text { in plasma and lung } \\
\text { Reduced bromine-induced } \\
\text { cytokine/chemokine levels } \\
\text { Reduced mortality }\end{array}$ & Nagy et al., 2010 \\
\hline Malaria PCC-infected mouse (DBA/2) & $\begin{array}{l}\text { Liver-specific overexpression of } \mathrm{HO}-1 \\
\text { using recombinant adenovirus }\end{array}$ & $\begin{array}{l}\text { Blocked hepatic failure indicated by the } \\
\text { decrease in AST and reduced tissue } \\
\text { necrosis } \\
\text { Prevented mortality }\end{array}$ & Seixas et al., 2009 \\
\hline S+S-Antilles SCD mouse (C57BL/6) & $\begin{array}{l}\text { Liver targeted rat } \mathrm{HO}-1 \text { gene delivery } \\
\text { by Sleeping Beauty transposase } \\
\text { system }\end{array}$ & $\begin{array}{l}\text { Reduced hypoxia-induced stasis in dorsal } \\
\text { skin fold chambers }\end{array}$ & Belcher et al., 2006 \\
\hline
\end{tabular}

AST, aspartate amino transferase; BAC, bacterial artificial chromosome.

in vitro and in vivo studies have revealed that specific upregulation of $\mathrm{HO}-1$ via heme or low doses of $\mathrm{Hb}$ provide beneficial effects in various preclinical models of experimental pathological conditions such as endotoxin-mediated lung injury in rats (Otterbein et al., 1995), human immunodeficiency syndrome (Levere et al., 1991; Devadas and Dhawan, 2006) or diabetes (Ndisang et al., 2009) (for reviews see Ryter et al., 2006; Abraham and Kappas, 2008). Although, heme has been established in the clinic for treatment of acute attacks in hepatic porphyrias (Bonkowsky et al., 1971), it is important to note that administration of heme for other indications in clinical practice may be critical for two reasons. First, due to its detrimental effects, which have been discussed above, heme may aggravate inflammatory disorders. Second, heme preparations can be unstable and cause considerable side effects such as coagulopathies and vasculitis (Glueck et al., 1983; Goetsch and Bissell, 1986; Simionatto et al., 1988). Hence, the feasibility of heme as a therapy for broad medical indications appears to be questionable and needs further evaluation in clinical practice. A compound with better potential for translation into the clinic might be heme arginate, which appears to be less toxic than heme (Jeney et al., 2002) and is an approved therapy for treatment of hepatic porphyrias in various European countries (Mustajoki et al., 1986; Kordac et al., 1989). Notably, heme arginate was found to up-regulate HO-1 not only in healthy individuals (Doberer et al., 2010), but also in patients receiving deceased donor renal transplants in a recent phase IIB trial (Thomas et al., 2016). Nevertheless, further studies are required to establish the feasibility of heme arginate for clinical applications.

Further potential therapeutic applications of HO-1 may involve its cell type-specific modulation via pharmacological interventions. To this end we and others have identified regulatory pathways of $\mathrm{HO}-1$ induction such as the protein kinase $A$ and $G$ signaling cascades in hepatocytes or the phosphatidyl-inositol-3 kinase (PI3K)/Akt cascade in mononuclear cells as putative drug targets (Immenschuh et al., 1998a,b; Wijayanti et al., 2005; Paine et al., 2010; Motterlini and Foresti, 2014). Independently, HO-1 may be regulated via established pharmaceutical compounds that have already been approved for clinical indications. For example, approved pharmacological compounds that are known to up-regulate HO-1 are statins (Grosser et al., 2004; Lee et al., 2004) and 5-aminosalicylic acid (Horvath et al., 2008). Novel candidates for targeted HO-1 up-regulation may be identified among members of the rapidly growing number of HO-1 inducing dietary and phytochemical compounds such as curcumin, quercetin or carnosol (Balogun et al., 2003; Martin et al., 2004; Peterson et al., 2009; Shen et al., 2013; Son et al., 2013) (for reviews see Ryter et al., 2006; Li et al., 2007; Abraham et al., 2009; Paine et al., 2010; Lundvig et al., 2012; Calay and Mason, 2014; Motterlini and Foresti, 2014). Finally, it is remarkable that pharmacological up-regulation of nuclear factor E2 related-factor 2 (Nrf2), which is a key nuclear regulator of HO-1, provides specific protection against heme toxicity in mouse models of SCD (Keleku-Lukwete et al., 2015; Belcher et al., 2016).

The therapeutic potential of genetic strategies that apply targeted overexpression of $\mathrm{HO}-1$ for the clinic is currently not clear. Specific overexpression of $\mathrm{HO}-1$ via vector-based genetic approaches in endothelial cells and adipocytes have been demonstrated to have beneficial effects in transplantation and hypertension (Chauveau et al., 2002; Cao et al., 2011, 2012; Petersen et al., 2011).

In conclusion, further studies are required before therapeutic strategies that specifically target HO-1 may become applicable in clinical practice. 


\section{CONCLUSIONS AND OUTLOOK}

\section{Conclusions}

1. Excess free heme is toxic via pro-oxidant, cytotoxic and proinflammatory effects.

2. Heme toxicity plays a major pathophysiological role in classical hemolytic disorders such as SCD and malaria, but also in diseases, which are not typically associated with hemolysis including sepsis and atherosclerosis.

3. The scavenger protein $\mathrm{Hx}$ and the $\mathrm{HO}$ enzyme system specifically control homeostasis and toxicity of heme in physiological and pathophysiological conditions.

\section{Outlook}

1. Pharmacological applications of $\mathrm{Hx}$ and HOs are promising therapeutic options to target the toxicity of heme in various clinical settings.

2. Hx might be a near-future therapy to counteract the detrimental effects of excess extracellular free heme.

\section{REFERENCES}

Abraham, N. G., Cao, J., Sacerdoti, D., Li, X., and Drummond, G. (2009). Heme oxygenase: the key to renal function regulation. Am. J. Physiol. Renal Physiol. 297, F1137-F1152. doi: 10.1152/ajprenal.90449.2008

Abraham, N. G., Friedland, M. L., and Lever, R. (1983). "Heme metabolism in hepatic and erythroid cells," in Progress in Hematology, ed E. Brown (New York: Grune and Stratton), 75-130.

Abraham, N. G., and Kappas, A. (2005). Heme oxygenase and the cardiovascular-renal system. Free Radic. Biol. Med. 39, 1-25. doi: 10.1016/j.freeradbiomed.2005.03.010

Abraham, N. G., and Kappas, A. (2008). Pharmacological and clinical aspects of heme oxygenase. Pharmacol. Rev. 60, 79-127. doi: 10.1124/pr.107. 07104

Abraham, N. G., Lin, J. H., Schwartzman, M. L., Levere, R. D., and Shibahara, S. (1988). The physiological significance of heme oxygenase. Int. J. Biochem. 20, 543-558. doi: 10.1016/0020-711X(88)90093-6

Adams, P. A., and Berman, M. C. (1980). Kinetics and mechanism of the interaction between human serum albumin and monomeric haemin. Biochem. J. 191, 95-102. doi: 10.1042/bj1910095

Aft, R. L., and Mueller, G. C. (1984). Hemin-mediated oxidative degradation of proteins. J. Biol. Chem. 259, 301-305.

Aft, R. L., and Mueller, G. C. (1983). Hemin-mediated DNA strand scission. J. Biol. Chem. 258, 12069-12072.

Aggarwal, S., Lam, A., Bolisetty, S., Carlisle, M. A., Traylor, A., Agarwal, A., et al. (2016). Heme attenuation ameliorates irritant gas inhalation-induced acute lung injury. Antioxid. Redox Signal. 24, 99-112. doi: 10.1089/ars.2015.6347

Allhorn, M., Berggard, T., Nordberg, J., Olsson, M. L., and Akerstrom, B. (2002). Processing of the lipocalin $\alpha_{1}$-microglobulin by hemoglobin induces heme-binding and heme-degradation properties. Blood 99, 1894-1901. doi: 10.1182/blood.V99.6.1894

Alvarado, G., Jeney, V., Toth, A., Csosz, E., Kallo, G., Huynh, A. T., et al. (2015). Heme-induced contractile dysfunction in human cardiomyocytes caused by oxidant damage to thick filament proteins. Free Radic. Biol. Med. 89, 248-262. doi: 10.1016/j.freeradbiomed.2015.07.158

Andrade, B. B., Araujo-Santos, T., Luz, N. F., Khouri, R., Bozza, M. T., Camargo, L. M., et al. (2010). Heme impairs prostaglandin E2 and TGF- $\beta$ production by human mononuclear cells via $\mathrm{Cu} / \mathrm{Zn}$ superoxide dismutase: insight into the pathogenesis of severe malaria. J. Immunol. 185, 1196-1204. doi: 10.4049/jimmunol.0904179

Angus, D. C., and van der Poll, T. (2013). Severe sepsis and septic shock. N. Engl. J. Med. 369, 840-851. doi: 10.1056/NEJMra1208623
3. Potential therapeutic strategies that apply targeted modulation of $\mathrm{HO}-1$ require further detailed studies.

4. A better understanding of the mechanisms that mediate heme toxicity in pathophysiology of various diseases is required to afford the development of innovative therapeutic interventions.

5. Diagnostic tests to determine free heme concentrations in plasma and tissues are necessary to achieve these goals.

\section{AUTHOR CONTRIBUTIONS}

SI, VV, SJ, and FG participated in conceptual work and writing of the manuscript.

\section{FUNDING}

Work in SI's laboratory is supported by grant IM 20/4-1 from the Deutsche Forschungsgemeinschaft, Bonn (Germany) and grant EKFS 2012_A309 from the Else Kröner Fresenius Stiftung, Bad Homburg (Germany).

Baek, J. H., D’Agnillo, F., Vallelian, F., Pereira, C. P., Williams, M. C., Jia, Y., et al. (2012). Hemoglobin-driven pathophysiology is an in vivo consequence of the red blood cell storage lesion that can be attenuated in guinea pigs by haptoglobin therapy. J. Clin. Invest. 122, 1444-1458. doi: 10.1172/JCI59770

Bakker, W. W., Borghuis, T., Harmsen, M. C. A., Van den Berg, A., Kema, I. P., Niezen, K. E., et al. (2005). Protease activity of plasma hemopexin. Kidney Int. 68, 603-610. doi: 10.1111/j.1523-1755.2005.00438.x

Balla, G., Jacob, H. S., Balla, J., Rosenberg, M., Nath, K., Apple, F., et al. (1992). Ferritin: a cytoprotective antioxidant strategem of endothelium. J. Biol. Chem. 267, 18148-18153.

Balla, G., Vercellotti, G. M., Muller-Eberhard, U., Eaton, J., and Jacob, H. S. (1991). Exposure of endothelial cells to free heme potentiates damage mediated by granulocytes and toxic oxygen species. Lab. Invest. 64, 648-655.

Balla, J., Jacob, H. S., Balla, G., Nath, K., Eaton, J. W., and Vercellotti, G. (1993). Endothelial-cell heme uptake from heme proteins: induction of sensitization and desensitization to oxidant damage. Proc. Natl. Acad. Sci. U.S.A. 90, 9285-9289. doi: 10.1073/pnas.90.20.9285

Balogun, E., Hoque, M., Gong, P., Killeen, E., Green, C. J., Foresti, R., et al. (2003). Curcumin activates the haem oxygenase-1 gene via regulation of Nrf2 and the antioxidant-responsive element. Biochem. J. 371, 887-895. doi: 10.1042/bj20021619

Baumann, H., and Gauldie, J. (1994). The acute phase response. Immunol. Today 15, 74-80. doi: 10.1016/0167-5699(94)90137-6

Bean, C. J., Boulet, S. L., Ellingsen, D., Pyle, M. E., Barron-Casella, E. A., Casella, J. F., et al. (2012). Heme oxygenase-1 gene promoter polymorphism is associated with reduced incidence of acute chest syndrome among children with sickle cell disease. Blood 120, 3822-3828. doi: 10.1182/blood-2011-06-361642

Belcher, J. D., Bryant, C. J., Nguyen, J., Bowlin, P. R., Kielbik, M. C., Bischof, J. C., et al. (2003). Transgenic sickle mice have vascular inflammation. Blood 101, 3953-3959. doi: 10.1182/blood-2002-10-3313

Belcher, J. D., Chen, C., Nguyen, J., Milbauer, L., Abdulla, F., Alayash, A. I., et al. (2014). Heme triggers TLR4 signaling leading to endothelial cell activation and vaso-occlusion in murine sickle cell disease. Blood 123, 377-390. doi: 10.1182/blood-2013-04-495887

Belcher, J. D., Chen, C., Nguyen, J., Zhang, P., Abdulla, F., Nguyen, P., et al. (2016). Control of oxidative stress and inflammation in sickle cell disease with the Nrf2 activator dimethyl fumarate. Antioxid. Redox Signal. doi: 10.1089/ars.2015.6571. [Epub ahead of print].

Belcher, J. D., Mahaseth, H., Welch, T. E., Otterbein, L. E., Hebbel, R. P., and Vercellotti, G. M. (2006). Heme oxygenase-1 is a modulator of inflammation and vaso-occlusion in transgenic sickle mice. J. Clin. Invest. 116, 808-816. doi: 10.1172/JCI26857 
Belcher, J. D., Vineyard, J. V., Bruzzone, C. M., Chen, C., Beckman, J. D., Nguyen, J., et al. (2010). Heme oxygenase-1 gene delivery by sleeping beauty inhibits vascular stasis in a murine model of sickle cell disease. J. Mol. Med. (Berl.) 88, 665-675. doi: 10.1007/s00109-010-0613-6

Bissell, D. M., Hammaker, L., and Schmid, R. (1972). Hemoglobin and erythrocyte catabolism in rat liver: the separate roles of parenchymal and sinusoidal cells. Blood 40, 812-822.

Bolisetty, S., Zarjou, A., Hull, T. D., Traylor, A. M., Perianayagam, A., Joseph, R., et al. (2015). Macrophage and epithelial cell $\mathrm{H}$-ferritin expression regulates renal inflammation. Kidney Int. 88, 95-108. doi: 10.1038/ki.2015.102

Bone, R. C. (1991). Let's agree on terminology: definitions of sepsis. Crit. Care Med. 19, 973-976. doi: 10.1097/00003246-199107000-00024

Bonkowsky, H. L., Tschudy, D. P., Collins, A., Doherty, J., Bossenmaier, I., Cardinal, R., et al. (1971). Repression of the overproduction of porphyrin precursors in acute intermittent porphyria by intravenous infusions of hematin. Proc. Natl. Acad. Sci. U.S.A. 68, 2725-2729. doi: 10.1073/pnas.68.11.2725

Bunn, H. F., and Jandl, J. H. (1968). Exchange of heme among hemoglobins and between hemoglobin and albumin. J. Biol. Chem. 243, 465-475.

Burris, T. P. (2008). Nuclear hormone receptors for heme: REV-ERB $\alpha$ and REV-ERB $\beta$ are ligand-regulated components of the mammalian clock. Mol. Endocrinol. 22, 1509-1520. doi: 10.1210/me.2007-0519

Calay, D., and Mason, J. C. (2014). The multifunctional role and therapeutic potential of HO-1 in the vascular endothelium. Antioxid. Redox Signal. 20, 1789-1809. doi: 10.1089/ars.2013.5659

Camus, S. M., De Moraes, J. A., Bonnin, P., Abbyad, P., Le Jeune, S., Lionnet, F., et al. (2015). Circulating cell membrane microparticles transfer heme to endothelial cells and trigger vasoocclusions in sickle cell disease. Blood 125, 3805-3814. doi: 10.1182/blood-2014-07-589283

Cao, J., Peterson, S. J., Sodhi, K., Vanella, L., Barbagallo, I., Rodella, L. F., et al. (2012). Heme oxygenase gene targeting to adipocytes attenuates adiposity and vascular dysfunction in mice fed a high-fat diet. Hypertension 60, 467-475. doi: 10.1161/HYPERTENSIONAHA.112.193805

Cao, J., Sodhi, K., Inoue, K., Quilley, J., Rezzani, R., Rodella, L., et al. (2011). Lentiviral-human heme oxygenase targeting endothelium improved vascular function in angiotensin II animal model of hypertension. Hum. Gene Ther. 22, 271-282. doi: 10.1089/hum.2010.059

Chakravarti, R., Aulak, K. S., Fox, P. L., and Stuehr, D. J. (2010). GAPDH regulates cellular heme insertion into inducible nitric oxide synthase. Proc. Natl. Acad. Sci. U.S.A. 107, 18004-18009. doi: 10.1073/pnas. 1008133107

Chance, B. (1967). The reactivity of haemoproteins and cytochromes. Biochem. J. 103, 1-18. doi: 10.1042/bj1030001

Chauveau, C., Bouchet, D., Roussel, J. C., Mathieu, P., Braudeau, C., Renaudin, K., et al. (2002). Gene transfer of heme oxygenase-1 and carbon monoxide delivery inhibit chronic rejection. Am. J. Transplant. 2, 581-592. doi: $10.1034 / j .1600-6143.2002 .20702 . x$

Chen, G., Zhang, D., Fuchs, T. A., Manwani, D., Wagner, D. D., and Frenette, P. S. (2014). Heme-induced neutrophil extracellular traps contribute to the pathogenesis of sickle cell disease. Blood 123, 3818-3827. doi: 10.1182/blood-2013-10-529982

Cheung, P. K., Stulp, B., Immenschuh, S., Borghuis, T., Baller, J. F., and Bakker, W. (1999). Is $100 \mathrm{KF}$ an isoform of hemopexin? Immunochemical characterization of the vasoactive plasma factor 100KF. J. Am. Soc. Nephrol. 10, 1700-1708.

Chiabrando, D., Vinchi, F., Fiorito, V., Mercurio, S., and Tolosano, E. (2014). Heme in pathophysiology: a matter of scavenging, metabolism and trafficking across cell membranes. Front. Pharmacol. 5:61. doi: 10.3389/fphar.2014.00061

Deuel, J. W., Vallelian, F., Schaer, C. A., Puglia, M., Buehler, P. W., and Schaer, D. J. (2015). Different target specificities of haptoglobin and hemopexin define a sequential protection system against vascular hemoglobin toxicity. Free Radic. Biol. Med. 89, 931-943. doi: 10.1016/j.freeradbiomed.2015.09.016

Devadas, K., and Dhawan, S. (2006). Hemin activation ameliorates HIV-1 infection via heme oxygenase-1 induction. J. Immunol. 176, 4252-4257. doi: 10.4049/jimmunol.176.7.4252

Doberer, D., Haschemi, A., Andreas, M., Zapf, T. C., Clive, B., Jeitler, M., et al. (2010). Haem arginate infusion stimulates haem oxygenase1 expression in healthy subjects. Br. J. Pharmacol. 161, 1751-1762. doi: 10.1111/j.1476-5381.2010.00990.x

Dorresteijn, M. J., Paine, A., Zilian, E., Fenten, M. G., Frenzel, E., Janciauskiene, S., et al. (2015). Cell-type-specific downregulation of heme oxygenase-1 by lipopolysaccharide via Bach1 in primary human mononuclear cells. Free Radic Biol. Med. 78, 224-232. doi: 10.1016/j.freeradbiomed.2014.10.579

Dutra, F. F., Alves, L. S., Rodrigues, D., Fernandez, P. L., de Oliveira, R. B., Golenbock, D. T., et al. (2014). Hemolysis-induced lethality involves inflammasome activation by heme. Proc. Natl. Acad. Sci. U.S.A. 111, E4110E4118. doi: 10.1073/pnas.1405023111

Dutra, F. F., and Bozza, M. T. (2014). Heme on innate immunity and inflammation. Front. Pharmacol. 5:115. doi: 10.3389/fphar.2014.00115

Elphinstone, R. E., Conroy, A. L., Hawkes, M., Hermann, L., Namasopo, S. Warren, H. S., et al. (2016). Alterations in systemic extracellular heme and hemopexin are associated with adverse clinical outcomes in Ugandan children with severe malaria. J. Infect. Dis. 214, 1268-1275. doi: 10.1093/infdis/jiw357

Exner, M., Minar, E., Wagner, O., and Schillinger, M. (2004). The role of heme oxygenase-1 promoter polymorphisms in human disease. Free Radic. Biol. Med. 37, 1097-1104. doi: 10.1016/j.freeradbiomed.2004.07.008

Figueiredo, R. T., Fernandez, P. L., Mourao-Sa, D. S., Porto, B. N., Dutra, F. F., Alves, L. S., et al. (2007). Characterization of heme as activator of Toll-like receptor 4. J. Biol. Chem. 282, 20221-20229. doi: 10.1074/jbc.M610737200

Frimat, M., Tabarin, F., Dimitrov, J. D., Poitou, C., Halbwachs-Mecarelli, L., Fremeaux-Bacchi, V., et al. T. (2013). Complement activation by heme as a secondary hit for atypical hemolytic uremic syndrome. Blood 122, 282-292. doi: 10.1182/blood-2013-03-489245

Ghosh, S., Adisa, O. A., Chappa, P., Tan, F., Jackson, K. A., Archer, D. R., et al. Ofori-Acquah (2013). Extracellular hemin crisis triggers acute chest syndrome in sickle mice. J. Clin. Invest. 123, 4809-4820. doi: 10.1172/JCI64578

Girvan, H. M., and Munro, A. W. (2013). Heme sensor proteins. J. Biol. Chem. 288, 13194-13203. doi: 10.1074/jbc.R112.422642

Glueck, R., Green, D., Cohen, I., and Ts'ao, C. H. (1983). Hematin: unique effects of hemostasis. Blood 61, 243-249.

Goetsch, C. A., and Bissell, D. M. (1986). Instability of hematin used in the treatment of acute hepatic porphyria. N. Engl. J. Med. 315, 235-238. doi: 10.1056/NEJM198607243150406

Gotts, J. E., and Matthay, M. A. (2016). Sepsis: pathophysiology and clinical management. BMJ 353:i1585. doi: 10.1136/bmj.i1585

Gozzelino, R., Jeney, V., and Soares, M. P. (2010). Mechanisms of cell protection by heme oxygenase-1. Annu. Rev. Pharmacol. Toxicol. 50, 323-354. doi: 10.1146/annurev.pharmtox.010909.105600

Gram, M., Sveinsdottir, S., Cinthio, M., Sveinsdottir, K., Hansson, S. R., Morgelin, M., et al. (2014). Extracellular hemoglobin - mediator of inflammation and cell death in the choroid plexus following preterm intraventricular hemorrhage. $J$. Neuroinflammation 11:200. doi: 10.1186/s12974-014-0200-9

Granick, S., Sinclair, P., Sassa, S., and Grieninger, G. (1975). Effects by heme, insulin, and serum albumin on heme and protein synthesis in chick embryo liver cells cultured in a chemically defined medium, and a spectrofluorometric assay for porphyrin composition. J. Biol. Chem. 250, 9215-9225.

Graw, J. A., Mayeur, C., Rosales, I., Liu, Y., Sabbisetti, V. S., Riley, F. E., et al. (2016). Haptoglobin or hemopexin therapy prevents acute adverse effects of resuscitation after prolonged storage of red cells. Circulation 134, 945-960. doi: 10.1161/CIRCULATIONAHA.115.019955

Greil, J., Verga-Falzacappa, M. V., Echner, N. E., Behnisch, W., Bandapalli, O. R., Pechanska, P., et al. (2016). Mutating heme oxygenase-1 into a peroxidase causes a defect in bilirubin synthesis associated with microcytic anemia and severe hyperinflammation. Haematologica 101, e436-e439. doi: 10.3324/haematol.2016.147090

Griffiths, E., Cortes, A., Gilbert, N., Stevenson, P., MacDonald, S., and Pepper, D. (1995). Haemoglobin-based blood substitutes and sepsis. Lancet 345, 158-160. doi: 10.1016/S0140-6736(95)90168-X

Grosser, N., Hemmerle, A., Berndt, G., Erdmann, K., Hinkelmann, U., Schurger, S., et al. (2004). The antioxidant defense protein heme oxygenase 1 is a novel target for statins in endothelial cells. Free Radic. Biol. Med. 37, 2064-2071. doi: 10.1016/j.freeradbiomed.2004.09.009

Hada, H., Shiraki, T., Watanabe-Matsui, M., and Igarashi, K. (2014). Hemopexindependent heme uptake via endocytosis regulates the Bach1 transcription repressor and heme oxygenase gene activation. Biochim. Biophys. Acta 1840, 2351-2360. doi: 10.1016/j.bbagen.2014.02.029

Haldar, M., Kohyama, M., So, A. Y., Kc, W., Wu, X., Briseno, C. G., et al. (2014). Heme-mediated SPI-C induction promotes monocyte differentiation into ironrecycling macrophages. Cell 156, 1223-1234. doi: 10.1016/j.cell.2014.01.069 
Hamza, I., and Dailey, H. A. (2012). One ring to rule them all: trafficking of heme and heme synthesis intermediates in the metazoans. Biochim. Biophys. Acta 1823, 1617-1632. doi: 10.1016/j.bbamcr.2012.04.009

Harvey, J. W., and Beutler, E. (1982). Binding of heme by glutathione S-transferase: a possible role of the erythrocyte enzyme. Blood 60, 1227-1230.

Hebbel, R. P., Morgan, W. T., Eaton, J. W., and Hedlund, B. E. (1988). Accelerated autoxidation and heme loss due to instability of sickle hemoglobin. Proc. Natl. Acad. Sci. U.S.A. 85, 237-241. doi: 10.1073/pnas.85.1.237

Heinrich, P. C., Castell, J. V., and Andus, T. (1990). Interleukin-6 and the acute phase response. Biochem. J. 265, 621-636. doi: 10.1042/bj2650621

Horvath, K., Varga, C., Berko, A., Posa, A., Laszlo, F., and Whittle, B. J. (2008). The involvement of heme oxygenase-1 activity in the therapeutic actions of 5-aminosalicylic acid in rat colitis. Eur. J. Pharmacol. 581, 315-323. doi: 10.1016/j.ejphar.2007.12.004

Hvidberg, V., Maniecki, M. B., Jacobsen, C., Hojrup, P., Moller, H. J., and Moestrup, S. K. (2005). Identification of the receptor scavenging hemopexinheme complexes. Blood 106, 2572-2579. doi: 10.1182/blood-2005-03-1185

Immenschuh, S., Baumgart-Vogt, E., Tan, M., Iwahara, S., Ramadori, G., and Fahimi, H. D. (2003). Differential cellular and subcellular localization of hemebinding protein 23/peroxiredoxin I and heme oxygenase-1 in rat liver. $J$. Histochem. Cytochem. 51, 1621-1631. doi: 10.1177/002215540305101206

Immenschuh, S., Hinke, V., Ohlmann, A., Gifhorn-Katz, S., Katz, N., Jungermann, K., et al. (1998a). Transcriptional activation of the haem oxygenase-1 gene by cGMP via a cAMP response element/activator protein-1 element in primary cultures of rat hepatocytes. Biochem. J. 334(Pt 1), 141-146. doi: $10.1042 / b j 3340141$

Immenschuh, S., Kietzmann, T., Hinke, V., Wiederhold, M., Katz, N., and MullerEberhard, U. (1998b). The rat heme oxygenase-1 gene is transcriptionally induced via the protein kinase A signaling pathway in rat hepatocyte cultures. Mol. Pharmacol. 53, 483-491.

Immenschuh, S., Nagae, Y., Satoh, H., Baumann, H., and Muller-Eberhard, U. (1994). The rat and human hemopexin genes contain an identical interleukin6 response element that is not a target of CAAT enhancer-binding protein isoforms. J. Biol. Chem. 269, 12654-12661.

Immenschuh, S., and Ramadori, G. (2000). Gene regulation of heme oxygenase-1 as a therapeutic target. Biochem. Pharmacol. 60, 1121-1128. doi: 10.1016/S0006-2952(00)00443-3

Immenschuh, S., Tan, M., and Ramadori, G. (1999). Nitric oxide mediates the lipopolysaccharide dependent upregulation of the heme oxygenase1 gene expression in cultured rat Kupffer cells. J. Hepatol. 30, 61-69. doi: $10.1016 /$ S0168-8278(99)80008-7

Ingram, V. M. (1957). Gene mutations in human haemoglobin: the chemical difference between normal and sickle cell haemoglobin. Nature 180, 326-328. doi: 10.1038/180326a0

Iwahara, S., Satoh, H., Song, D. X., Webb, J., Burlingame, A. L., Nagae, Y., et al. (1995). Purification, characterization and cloning of a hemebinding protein $(23 \mathrm{kDa})$ in rat liver cytosol. Biochemistry 34, 13398-13406. doi: 10.1021/bi00041a017

Janz, D. R., Bastarache, J. A., Sills, G., Wickersham, N., May, A. K., Bernard, G. R., et al. (2013). Association between haptoglobin, hemopexin and mortality in adults with sepsis. Crit. Care 17:R272. doi: 10.1186/cc13108

Jeney, V., Balla, G., and Balla, J. (2014). Red blood cell, hemoglobin and heme in the progression of atherosclerosis. Front. Physiol. 5:379. doi: 10.3389/fphys.2014.00379

Jeney, V., Balla, J., Yachie, A., Varga, Z., Vercellotti, G. M., Eaton, J. W., et al. (2002). Pro-oxidant and cytotoxic effects of circulating heme. Blood 100, 879-887. doi: 10.1182/blood.V100.3.879

Kapturczak, M. H., Wasserfall, C., Brusko, T., Campbell-Thompson, M., Ellis, T. M., Atkinson, M. A., et al. (2004). Heme oxygenase-1 modulates early inflammatory responses: evidence from the heme oxygenase-1-deficient mouse. Am. J. Pathol. 165, 1045-1053. doi: 10.1016/S0002-9440(10)63365-2

Karnaukhova, E., Krupnikova, S. S., Rajabi, M., and Alayash, A. I. (2012). Heme binding to human alpha-1 proteinase inhibitor. Biochim. Biophys. Acta 1820, 2020-2029. doi: 10.1016/j.bbagen.2012.09.012

Keleku-Lukwete, N., Suzuki, M., Otsuki, A., Tsuchida, K., Katayama, S., Hayashi, M., et al. (2015). Amelioration of inflammation and tissue damage in sickle cell model mice by Nrf2 activation. Proc. Natl. Acad. Sci. U.S.A. 112, 12169-12174. doi: 10.1073/pnas.1509158112
Khechaduri, A., Bayeva, M., Chang, H. C., and Ardehali, H. (2013). Heme levels are increased in human failing hearts. J. Am. Coll. Cardiol. 61, 1884-1893. doi: 10.1016/j.jacc.2013.02.012

Kordac, V., Kozakova, M., and Martasek, P. (1989). Changes of myocardial functions in acute hepatic porphyrias. Role of heme arginate administration. Ann. Med. 21, 273-276. doi: 10.3109/07853898909149205

Kovtunovych, G., Eckhaus, M. A., Ghosh, M. C., Ollivierre-Wilson, H., and Rouault, T. A. (2010). Dysfunction of the heme recycling system in heme oxygenase 1-deficient mice: effects on macrophage viability and tissue iron distribution. Blood 116, 6054-6062. doi: 10.1182/blood-2010-03272138

Kumar, S., and Bandyopadhyay, U. (2005). Free heme toxicity and its detoxification systems in human. Toxicol. Lett. 157, 175-188. doi: 10.1016/j.toxlet.2005.03.004

Kutty, R. K., and Maines, M. D. (1981). Purification and characterization of biliverdin reductase from rat liver. J. Biol. Chem. 256, 3956-3962.

Larsen, R., Gouveia, Z., Soares, M. P., and Gozzelino, R. (2012). Heme cytotoxicity and the pathogenesis of immune-mediated inflammatory diseases. Front. Pharmacol. 3:77. doi: 10.3389/fphar.2012.00077

Larsen, R., Gozzelino, R., Jeney, V., Tokaji, L., Bozza, F. A., Japiassu, A. M., et al. (2010). A central role for free heme in the pathogenesis of severe sepsis. Sci. Transl. Med. 2:51ra71. doi: 10.1126/scitranslmed.3001118

Lee, T. S., Chang, C. C., Zhu, Y., and Shyy, J. Y. (2004). Simvastatin induces heme oxygenase-1: a novel mechanism of vessel protection. Circulation 110, 1296-1302. doi: 10.1161/01.CIR.0000140694.67251.9C

Lelubre, C., Piagnerelli, M., and Vincent, J. L. (2009). Association between duration of storage of transfused red blood cells and morbidity and mortality in adult patients: myth or reality? Transfusion 49, 1384-1394. doi: 10.1111/j.1537-2995.2009.02211.x

Lever, J. M., Boddu, R., George, J. F., and Agarwal, A. (2016). Heme oxygenase1 in kidney health and disease. Antioxid. Redox Signal. 25, 165-183. doi: 10.1089/ars.2016.6659

Levere, R. D., Gong, Y. F., Kappas, A., Bucher, D. J., Wormser, G. P., and Abraham, N. G. (1991). Heme inhibits human immunodeficiency virus 1 replication in cell cultures and enhances the antiviral effect of zidovudine. Proc. Natl. Acad. Sci. U.S.A. 88, 1756-1759. doi: 10.1073/pnas.88.5.1756

Li, C., Hossieny, P., Wu, B. J., Qawasmeh, A., Beck, K., and Stocker, R. (2007). Pharmacologic induction of heme oxygenase-1. Antioxid. Redox Signal. 9, 2227-2239. doi: 10.1089/ars.2007.1783

Liem, H. H., Noy, N., and Muller-Eberhard, U. (1994). Studies on the efflux of heme from biological membranes. Biochim. Biophys. Acta 1194, 264-270. doi: 10.1016/0005-2736(94)90308-5

Lin, T., Kwak, Y. H., Sammy, F., He, P., Thundivalappil, S., Sun, G., et al. (2010). Synergistic inflammation is induced by blood degradation products with microbial Toll-like receptor agonists and is blocked by hemopexin. $J$. Infect. Dis. 202, 624-632. doi: 10.1086/654929

Lin, T., Liu, J., Huang, F., Van Engelen, T. S., Thundivalappil, S. R., Riley, F. E., et al. (2016). Purified and recombinant hemopexin: protease activity and effect on neutrophil chemotaxis. Mol. Med. 22, 22-31. doi: 10.2119/molmed.2016. 00006

Lin, T., Maita, D., Thundivalappil, S. R., Riley, F. E., Hambsch, J., Van Marter, L. J., et al. (2015). Hemopexin in severe inflammation and infection: mouse models and human diseases. Crit. Care 19:166. doi: 10.1186/s13054-015-0885-x

Little, H. N., and Neilands, J. B. (1960). Binding of haematin by human serum albumin. Nature 188, 913-915. doi: 10.1038/188913a0

Lundvig, D. M., Immenschuh, S., and Wagener, F. A. (2012). Heme oxygenase, inflammation, and fibrosis: the good, the bad, and the ugly? Front. Pharmacol. 3:81. doi: 10.3389/fphar.2012.00081

Ma, B., Day, J. P., Phillips, H., Slootsky, B., Tolosano, E., and Dore, S. (2016). Deletion of the hemopexin or heme oxygenase-2 gene aggravates brain injury following stroma-free hemoglobin-induced intracerebral hemorrhage. J. Neuroinflammation 13:26. doi: 10.1186/s12974-016-0490-1

Maines, M. D. (1997). The heme oxygenase system: a regulator of second messenger gases. Annu. Rev. Pharmacol. Toxicol. 37, 517-554. doi: 10.1146/annurev.pharmtox.37.1.517

Maines, M. D., and Kappas, A. (1974). Cobalt induction of hepatic heme oxygenase; with evidence that cytochrome P-450 is not essential for this enzyme activity. Proc. Natl. Acad. Sci. U.S.A. 71, 4293-4297. doi: $10.1073 /$ pnas.71.11.4293 
Martin, D., Rojo, A. I., Salinas, M., Diaz, R., Gallardo, G., Alam, J., et al. (2004). Regulation of heme oxygenase-1 expression through the phosphatidylinositol 3-kinase/Akt pathway and the Nrf2 transcription factor in response to the antioxidant phytochemical carnosol. J. Biol. Chem. 279, 8919-8929. doi: 10.1074/jbc.M309660200

Mendonca, V. R., Luz, N. F., Santos, N. J., Borges, V. M., Goncalves, M. S., Andrade, B. B., et al. (2012). Association between the haptoglobin and heme oxygenase 1 genetic profiles and soluble CD163 in susceptibility to and severity of human malaria. Infect. Immun. 80, 1445-1454. doi: 10.1128/IAI.05933-11

Mense, S. M., and Zhang, L. (2006). Heme: a versatile signaling molecule controlling the activities of diverse regulators ranging from transcription factors to MAP kinases. Cell Res. 16, 681-692. doi: 10.1038/sj.cr.7310086

Mestas, J., and Hughes, C. C. (2004). Of mice and not men: differences between mouse and human immunology. J. Immunol. 172, 2731-2738. doi: 10.4049/jimmunol.172.5.2731

Miller, L. H., Baruch, D. I., Marsh, K., and Doumbo, O. K. (2002). The pathogenic basis of malaria. Nature 415, 673-679. doi: 10.1038/415673a

Miyazaki, T., Kirino, Y., Takeno, M., Samukawa, S., Hama, M., Tanaka, M., et al. (2010). Expression of heme oxygenase-1 in human leukemic cells and its regulation by transcriptional repressor Bach1. Cancer Sci. 101, 1409-1416. doi: 10.1111/j.1349-7006.2010.01550.x

Mosser, D. M., and Edwards, J. P. (2008). Exploring the full spectrum of macrophage activation. Nat. Rev. Immunol. 8, 958-969. doi: 10.1038/nri2448

Motterlini, R., and Foresti, R. (2014). Heme oxygenase-1 as a target for drug discovery. Antioxid. Redox Signal. 20, 1810-1826. doi: 10.1089/ars.2013.5658

Muller Eberhard, U. (1970). Hemopexin. N. Engl. J. Med. 283, 1090-1094. doi: 10.1056/NEJM197011122832007

Muller-Eberhard, U., and Cleve, H. (1963). Immunoelectrophoretic studies of the beta1-haem-binding globulin (haemopexin) in hereditary haemolytic disorders. Nature 197, 602-603. doi: 10.1038/197602a0

Muller-Eberhard, U., Javid, J., Liem, H. H., Hanstein, A., and Hanna, M. (1968). Plasma concentrations of hemopexin, haptoglobin and heme in patients with various hemolytic diseases. Blood 32, 811-815.

Muller Eberhard, U., and Nikkilä, H. (1989). Transport of tetrapyrroles by proteins. Semin. Hematol. 26, 86-104.

Mustajoki, P., Tenhunen, R., Tokola, O., and Gothoni, G. (1986). Haem arginate in the treatment of acute hepatic porphyrias. Br. Med. J. (Clin. Res. Ed.) 293, 538-539. doi: 10.1136/bmj.293.6546.538-a

Nagy, E., Eaton, J. W., Jeney, V., Soares, M. P., Varga, Z., Galajda, Z., et al. (2010). Red cells, hemoglobin, heme, iron, and atherogenesis. Arterioscler. Thromb. Vasc. Biol. 30, 1347-1353. doi: 10.1161/ATVBAHA.110.206433

Nakamichi, I., Habtezion, A., Zhong, B., Contag, C. H., Butcher, E. C., and Omary, M. B. (2005). Hemin-activated macrophages home to the pancreas and protect from acute pancreatitis via heme oxygenase-1 induction. J. Clin. Invest. 115, 3007-3014. doi: 10.1172/JCI24912

Nath, K. A., Balla, G., Vercellotti, G. M., Balla, J., Jacob, H. S., Levitt, M. D., et al. (1992). Induction of heme oxygenase is a rapid, protective response in rhabdomyolysis in the rat. J. Clin. Invest. 90, 267-270. doi: 10.1172/JCI115847

Nath, K. A., Balla, J., Croatt, A. J., and Vercellotti, G., and M. (1995). Heme proteinmediated renal injury: a protective role for 21 -aminosteroids in vitro and in vivo. Kidney Int. 47, 592-602. doi: 10.1038/ki.1995.75

Nath, K. A., and Katusic, Z. S. (2012). Vasculature and kidney complications in sickle cell disease. J. Am. Soc. Nephrol. 23, 781-784. doi: 10.1681/ASN.2011101019

Ndisang, J. F., Lane, N., and Jadhav, A. (2009). The heme oxygenase system abates hyperglycemia in Zucker diabetic fatty rats by potentiating insulin-sensitizing pathways. Endocrinology 150, 2098-2108. doi: 10.1210/en.2008-0239

Otterbein, L., Sylvester, S. L., and Choi, A. M. (1995). Hemoglobin provides protection against lethal endotoxemia in rats: the role of heme oxygenase-1. Am. J. Respir. Cell Mol. Biol. 13, 595-601. doi: 10.1165/ajrcmb.13.5.7576696

Paine, A., Eiz-Vesper, B., Blasczyk, R., and Immenschuh, S. (2010). Signaling to heme oxygenase-1 and its anti-inflammatory therapeutic potential. Biochem. Pharmacol. 80, 1895-1903. doi: 10.1016/j.bcp.2010.07.014

Pamplona, A., Ferreira, A., Balla, J., Jeney, V., Balla, G., Epiphanio, S., et al. (2007). Heme oxygenase-1 and carbon monoxide suppress the pathogenesis of experimental cerebral malaria. Nat. Med. 13, 703-710. doi: 10.1038/nm1586

Paoli, M., Anderson, B. F., Baker, H. M., Morgan, W. T., Smith, A., Baker, E., et al. (1999). Crystal structure of hemopexin reveals a novel high-affinity heme site formed between two $\beta$-propeller domains. Nat. Struct. Biol. 6, 926-931. doi: 10.1038/13294

Paul, G., Bataille, F., Obermeier, F., Bock, J., Klebl, F., Strauch, U., et al. (2005). Analysis of intestinal haem-oxygenase-1 (HO-1) in clinical and experimental colitis. Clin. Exp. Immunol. 140, 547-555. doi: 10.1111/j.1365-2249.2005.02775.x

Pechlaner, R., Willeit, P., Summerer, M., Santer, P., Egger, G., Kronenberg, F., et al. (2015). Heme oxygenase-1 gene promoter microsatellite polymorphism is associated with progressive atherosclerosis and incident cardiovascular disease. Arterioscler. Thromb. Vasc. Biol. 35, 229-236. doi: 10.1161/ATVBAHA.114.304729

Petersen, B., Ramackers, W., Lucas-Hahn, A., Lemme, E., Hassel, P., Queisser, A. L., et al. (2011). Transgenic expression of human heme oxygenase-1 in pigs confers resistance against xenograft rejection during ex vivo perfusion of porcine kidneys. Xenotransplantation 18, 355-368. doi: 10.1111/j.1399-3089.2011.00674.x

Peterson, S. J., Kim, D. H., Li, M., Positano, V., Vanella, L., Rodella, L. F., et al. (2009). The L-4F mimetic peptide prevents insulin resistance through increased levels of HO-1, pAMPK, and pAKT in obese mice. J. Lipid Res. 50, 1293-1304. doi: 10.1194/jlr.M800610-JLR200

Pober, J. S., Min, W., and Bradley, J. R. (2009). Mechanisms of endothelial dysfunction, injury, and death. Annu. Rev. Pathol. 4, 71-95. doi: 10.1146/ annurev.pathol.4.110807.092155

Poli, V., Mancini, F. P., and Cortese, R. (1990). IL-6DBP, a nuclear protein involved in interleukin-6 signal transduction, defines a new family of leucine zipper proteins related to C/EBP. Cell 63, 643-653. doi: 10.1016/0092-8674(90)90459-R

Ponka, P. (1997). Tissue-specific regulation of iron metabolism and heme synthesis: distinct control mechanisms in erythroid cells. Blood 89, 1-25.

Ponka, P. (1999). Cell biology of heme. Am. J. Med. Sci. 318, 241-256. doi: 10.1016/S0002-9629(15)40628-7

Poss, K. D., Thomas, M. J., Ebralidze, A. K., O’Dell, T. J., and Tonegawa, S. (1995). Hippocampal long-term potentiation is normal in heme oxygenase-2 mutant mice. Neuron 15, 867-873. doi: 10.1016/0896-6273(95)90177-9

Poss, K. D., and Tonegawa, S. (1997a). Reduced stress defense in heme oxygenase 1-deficient cells. Proc. Natl. Acad. Sci. U.S.A. 94, 10925-10930. doi: 10.1073/pnas.94.20.10925

Poss, K. D., and Tonegawa, S. (1997b). Heme oxygenase 1 is required for mammalian iron reutilization. Proc. Natl. Acad. Sci. U.S.A. 94, 10919-10924. doi: 10.1073/pnas.94.20.10919

Potter, D., Chroneos, Z. C., Baynes, J. W., Sinclair, P. R., Gorman, N., Liem, H. H., et al. (1993). In vivo fate of hemopexin and heme-hemopexin complexes in the rat. Arch. Biochem. Biophys. 300, 98-104. doi: 10.1006/abbi.1993.1014

Reeder, B. J. (2010). The redox activity of hemoglobins: from physiologic functions to pathologic mechanisms. Antioxid. Redox Signal. 13, 1087-1123. doi: 10.1089/ars.2009.2974

Rifkind, J. M., and Nagababu, E. (2013). Hemoglobin redox reactions and red blood cell aging. Antioxid. Redox Signal. 18, 2274-2283. doi: 10.1089/ars.2012.4867

Roumenina, L. T., Rayes, J., Lacroix-Desmazes, S., and Dimitrov, J. D. (2016). Heme: modulator of plasma systems in hemolytic diseases. Trends Mol. Med. 22, 200-213. doi: 10.1016/j.molmed.2016.01.004

Ryter, S. W., Alam, J., and Choi, A. M. (2006). Heme oxygenase-1/carbon monoxide: from basic science to therapeutic applications. Physiol. Rev. 86, 583-650. doi: 10.1152/physrev.00011.2005

Ryter, S. W., and Tyrrell, R. M. (2000). The heme synthesis and degradation pathways: role in oxidant sensitivity. Heme oxygenase has both pro- and antioxidant properties. Free Radic. Biol. Med. 28, 289-309. doi: 10.1016/S0891-5849(99)00223-3

Sadrzadeh, S. M., Anderson, D. K., Panter, S. S., Hallaway, P. E., and Eaton, J. W. (1987). Hemoglobin potentiates central nervous system damage. J. Clin. Invest. 79, 662-664. doi: 10.1172/JCI112865

Saragih, H., Zilian, E., Jaimes, Y., Paine, A., Figueiredo, C., Eiz-Vesper, B., et al. (2014). PECAM-1-dependent heme oxygenase-1 regulation via an Nrf2mediated pathway in endothelial cells. Thromb. Haemost. 111, 1077-1088. doi: 10.1160/TH13-11-0923

Satoh, T., Satoh, H., Iwahara, S., Hrkal, Z., Peyton, D. H., and MullerEberhard, U. (1994). Roles of heme iron-coordinating histidine residues of human hemopexin expressed in baculovirus-infected insect cells. 
Proc. Natl. Acad. Sci. U.S.A. 91, 8423-8427. doi: 10.1073/pnas.91. 18.8423

Sawicki, K. T., Shang, M., Wu, R., Chang, H. C., Khechaduri, A., Sato, T., et al. (2015). Increased Heme Levels in the Heart Lead to Exacerbated Ischemic Injury. J. Am. Heart Assoc. 4:e002272. doi: 10.1161/JAHA.115.002272

Schaedler, R. W., and Dubos, R. J. (1961). The susceptibility of mice to bacterial endotoxins. J. Exp. Med. 113, 559-570. doi: 10.1084/jem.113.3.559

Schaer, D. J., Buehler, P. W., Alayash, A. I., Belcher, J. D., and Vercellotti, G. M. (2012). Hemolysis and free hemoglobin revisited: exploring hemoglobin and hemin scavengers as a novel class of therapeutic proteins. Blood 121, 1276-1284. doi: 10.1182/blood-2012-11-451229

Schaer, D. J., Vinchi, F., Ingoglia, G., Tolosano, E., and Buehler, P. W. (2014). Haptoglobin, hemopexin, and related defense pathways-basic science, clinical perspectives, and drug development. Front. Physiol. 5:415. doi: 10.3389/fphys.2014.00415

Seixas, E., Gozzelino, R., Chora, A., Ferreira, A., Silva, G., Larsen, R., et al. (2009). Heme oxygenase-1 affords protection against noncerebral forms of severe malaria. Proc. Natl. Acad. Sci. U.S.A. 106, 15837-15842. doi: 10.1073/pnas.0903419106

Seok, J., Warren, H. S., Cuenca, A. G., Mindrinos, M. N., Baker, H. V., $\mathrm{Xu}, \mathrm{W}$., et al. (2013). Genomic responses in mouse models poorly mimic human inflammatory diseases. Proc. Natl. Acad. Sci. U.S.A. 110, 3507-3512. doi: $10.1073 /$ pnas. 1222878110

Shen, Y., Ward, N. C., Hodgson, J. M., Puddey, I. B., Wang, Y., Zhang, D., et al. (2013). Dietary quercetin attenuates oxidant-induced endothelial dysfunction and atherosclerosis in apolipoprotein $\mathrm{E}$ knockout mice fed a high-fat diet: a critical role for heme oxygenase-1. Free Radic. Biol. Med. 65, 908-915. doi: 10.1016/j.freeradbiomed.2013.08.185

Sikorski, E. M., Hock, T., Hill-Kapturczak, N., and Agarwal, A. (2004). The story so far: molecular regulation of the heme oxygenase-1 gene in renal injury. Am. J. Physiol. Renal Physiol. 286, F425-F441. doi: 10.1152/ajprenal.00297.2003

Simionatto, C. S., Cabal, R., Jones, R. L., and Galbraith, R. A. (1988). Thrombophlebitis and disturbed hemostasis following administration of intravenous hematin in normal volunteers. Am. J. Med. 85, 538-540. doi: $10.1016 / \mathrm{S} 0002-9343(88) 80092-5$

Smith, A., and McCulloh, R. J. (2015). Hemopexin and haptoglobin: allies against heme toxicity from hemoglobin not contenders. Front. Physiol. 6:187. doi: 10.3389/fphys.2015.00187

Soares, M. P., and Bozza, M. T. (2016). Red alert: labile heme is an alarmin. Curr. Opin. Immunol. 38, 94-100. doi: 10.1016/j.coi.2015.11.006

Solar, I., Muller-Eberhard, U., Shviro, Y., and Shaklai, N. (1991). Long-term intercalation of residual hemin in erythrocyte membranes distorts the cell. Biochim. Biophys. Acta 1062, 51-58. doi: 10.1016/0005-2736(91)90334-5

Son, Y., Lee, J. H., Chung, H. T., and Pae, H. O. (2013). Therapeutic roles of heme oxygenase-1 in metabolic diseases: curcumin and resveratrol analogues as possible inducers of heme oxygenase-1. Oxid. Med. Cell Longev. 2013:639541. doi: $10.1155 / 2013 / 639541$

Spiller, F., Costa, C., Souto, F. O., Vinchi, F., Mestriner, F. L., Laure, H. J., et al. (2011). Inhibition of neutrophil migration by hemopexin leads to increased mortality due to sepsis in mice. Am. J. Respir. Crit. Care Med. 183, 922-931. doi: $10.1164 / \mathrm{rccm} .201002-0223 \mathrm{OC}$

Stapley, R., Rodriguez, C., Oh, J. Y., Honavar, J., Brandon, A., Wagener, B. M., et al. (2015). Red blood cell washing, nitrite therapy, and antiheme therapies prevent stored red blood cell toxicity after trauma-hemorrhage. Free Radic. Biol. Med. 85, 207-218. doi: 10.1016/j.freeradbiomed.2015.04.025

Taketani, S., Adachi, Y., Kohno, H., Ikehara, S., Tokunaga, R., and Ishii, T. (1998). Molecular characterization of a newly identified heme-binding protein induced during differentiation of murine erythroleukemia cells. J. Biol. Chem. 273, 31388-31394. doi: 10.1074/jbc.273.47.31388

Tenhunen, R., Marver, H. S., and Schmid, R. (1968). The enzymatic conversion of heme to bilirubin by microsomal heme oxygenase. Proc. Natl. Acad. Sci. U.S.A. 61, 748-755. doi: 10.1073/pnas.61.2.748

Thomas, R. A., Czopek, A., Bellamy, C. O., McNally, S. J., Kluth, D. C., and Marson, L. P. (2016). Hemin preconditioning upregulates heme oxygenase-1 in deceased donor renal transplant recipients: a randomized, controlled, phase IIB trial. Transplantation 100, 176-183. doi: 10.1097/TP.0000000000000770

Tolosano, E., and Altruda, F. (2002). Hemopexin: structure, function, and regulation. DNA Cell Biol. 21, 297-306. doi: 10.1089/104454902753759717
Tolosano, E., Fagoonee, S., Hirsch, E., Berger, F. G., Baumann, H., Silengo, L., et al. (2002). Enhanced splenomegaly and severe liver inflammation in haptoglobin/hemopexin double-null mice after acute hemolysis. Blood 100, 4201-4208. doi: 10.1182/blood-2002-04-1270

Tolosano, E., Fagoonee, S., Morello, N., Vinchi, F., and Fiorito, V. (2010). Heme scavenging and the other facets of hemopexin. Antioxid. Redox Signal. 12, 305-320. doi: 10.1089/ars.2009.2787

Tolosano, E., Hirsch, E., Patrucco, E., Camaschella, C., Navone, R., Silengo, L., et al. (1999). Defective recovery and severe renal damage after acute hemolysis in hemopexin-deficient mice. Blood 94, 3906-3914.

Tracz, M. J., Alam, J., and Nath, K. A. (2007). Physiology and pathophysiology of heme: implications for kidney disease. J. Am. Soc. Nephrol. 18, 414-420. doi: 10.1681/ASN.2006080894

Trakshel, G. M., Kutty, R. K., and Maines, M. D. (1986). Purification and characterization of the major constitutive form of testicular heme oxygenase. The noninducible isoform. J. Biol. Chem. 261, 11131-11137.

True, A. L., Olive, M., Boehm, M., San, H., Westrick, R. J., Raghavachari, N., et al. (2007). Heme oxygenase-1 deficiency accelerates formation of arterial thrombosis through oxidative damage to the endothelium, which is rescued by inhaled carbon monoxide. Circ. Res. 101, 893-901. doi: 10.1161/CIRCRESAHA.107.158998

Tzima, S., Victoratos, P., Kranidioti, K., Alexiou, M., and Kollias, G. (2009). Myeloid heme oxygenase-1 regulates innate immunity and autoimmunity by modulating IFN- $\beta$ production. J. Exp. Med. 206, 1167-1179. doi: $10.1084 /$ jem.20081582

Vercellotti, G. M., Zhang, P., Nguyen, J., Abdulla, F., Chen, C., Nguyen, P., et al. (2016). Hepatic overexpression of hemopexin inhibits inflammation and vascular stasis in murine models of sickle cell disease. Mol. Med. 22, 437-451. doi: 10.2119/molmed.2016.00063

Vincent, S. H. (1989). Oxidative effects of heme and porphyrins on proteins and lipids. Semin. Hematol. 26, 105-113.

Vincent, S. H., Grady, R. W., Shaklai, N., Snider, J. M., and Muller-Eberhard, U. (1988). The influence of heme-binding proteins in heme-catalyzed oxidations. Arch. Biochem. Biophys. 265, 539-550. doi: 10.1016/0003-9861(88)90159-2

Vincent, S. H., and Muller Eberhard, U. (1985). A protein of the Z class of liver cytosolic proteins in the rat that preferentially binds heme. J. Biol. Chem. 260, 14521-14528.

Vinchi, F., De Franceschi, L., Ghigo, A., Townes, T., Cimino, J., Silengo, L., et al. (2013). Hemopexin therapy improves cardiovascular function by preventing heme-induced endothelial toxicity in mouse models of hemolytic diseases. Circulation 127, 1317-1329. doi: 10.1161/CIRCULATIONAHA.112. 130179

Vinchi, F., Gastaldi, S., Silengo, L., Altruda, F., and Tolosano, E. (2008). Hemopexin prevents endothelial damage and liver congestion in a mouse model of heme overload. Am. J. Pathol. 173, 289-299. doi: 10.2353/ajpath.2008.071130

Vinchi, F., Costa da Silva, M., Ingoglia, G., Petrillo, S., Brinkman, N., Zuercher, A., et al. (2016). Hemopexin therapy reverts heme-induced proinflammatory phenotypic switching of macrophages in a mouse model of sickle cell disease. Blood 127, 473-486. doi: 10.1182/blood-2015-08-663245

Wagener, E., Feldman, T., de Witte, T., and Abraham, N. G. (1997). Heme induces the expression of adhesion molecules ICAM-1, VCAM-1, and E selectin in vascular endothelial cells. Proc. Soc. Exp. Biol. Med. 216, 456-463. doi: 10.3181/00379727-216-44197

Wagener, F. A., Eggert, A., Boerman, O. C., Oyen, W. J., Verhofstad, A., Abraham, N. G., et al. (2001). Heme is a potent inducer of inflammation in mice and is counteracted by heme oxygenase. Blood 98, 1802-1811. doi: 10.1182/blood.V98.6.1802

Wagener, F. A., Volk, H. D., Willis, D., Abraham, N. G., Soares, M. P., Adema, G. J., et al. (2003). Different faces of the heme-heme oxygenase system in inflammation. Pharmacol. Rev. 55, 551-571. doi: 10.1124/pr.55.3.5

Wang, D., Cortes-Puch, I., Sun, J., Solomon, S. B., Kanias, T., Remy, K. E., et al. (2012a). Transfusion of older stored blood worsens outcomes in canines depending on the presence and severity of pneumonia. Transfusion 54, 1712-1724. doi: 10.1111/trf.12607

Wang, D., Sun, J., Solomon, S. B., Klein, H. G., and Natanson, C. (2012b). Transfusion of older stored blood and risk of death: a meta-analysis. Transfusion 52, 1184-1195. doi: 10.1111/j.1537-2995.2011.03466.x 
Warren, H. S., Tompkins, R. G., Moldawer, L. L., Seok, J., Xu, W., Mindrinos, M. N., et al. (2015). Mice are not men. Proc. Natl. Acad. Sci. U.S.A. 112:E345. doi: 10.1073/pnas.1414857111

Wei, Q., Hill, W. D., Su, Y., Huang, S., and Dong, Z. (2011). Heme oxygenase1 induction contributes to renoprotection by G-CSF during rhabdomyolysisassociated acute kidney injury. Am. J. Physiol. Renal Physiol. 301, F162-F170. doi: 10.1152/ajprenal.00438.2010

Wijayanti, N., Katz, N., and Immenschuh, S. (2004). Biology of heme in health and disease. Curr. Med. Chem. 11, 981-986. doi: 10.2174/09298670434 55521

Wijayanti, N., Kietzmann, T., and Immenschuh, S. (2005). Heme oxygenase1 gene activation by the $\mathrm{NAD}(\mathrm{P}) \mathrm{H}$ oxidase inhibitor 4-(2-aminoethyl) benzenesulfonyl fluoride via a protein kinase B, p38-dependent signaling pathway in monocytes. J. Biol. Chem. 280, 21820-21829. doi: 10.1074/jbc.M502943200

Yachie, A., Niida, Y., Wada, T., Igarashi, N., Kaneda, H., Toma, T., et al. (1999). Oxidative stress causes enhanced endothelial cell injury in human heme oxygenase-1 deficiency. J. Clin. Invest. 103, 129-135. doi: 10.1172/JCI4165

Yamada, N., Yamaya, M., Okinaga, S., Nakayama, K., Sekizawa, K., Shibahara, S., et al. (2000). Microsatellite polymorphism in the heme oxygenase-1 gene promoter is associated with susceptibility to emphysema. Am. J. Hum. Genet. 66, 187-195. doi: 10.1086/302729
Yuan, X., Rietzschel, N., Kwon, H., Walter Nuno, A. B., Hanna, D. A., Phillips, J. D., et al. (2016). Regulation of intracellular heme trafficking revealed by subcellular reporters. Proc. Natl. Acad. Sci. U.S.A. 113, E5144-E5152. doi: 10.1073/pnas.1609865113

Zarjou, A., Bolisetty, S., Joseph, R., Traylor, A., Apostolov, E. O., Arosio, P., et al. (2013). Proximal tubule H-ferritin mediates iron trafficking in acute kidney injury. J. Clin. Invest. 123, 4423-4434. doi: 10.1172/JCI67867

Zhong, H., Bao, W., Friedman, D., and Yazdanbakhsh, K. (2014). Hemin controls T cell polarization in sickle cell alloimmunization. J. Immunol. 193, 102-110. doi: $10.4049 /$ jimmunol.1400105

Conflict of Interest Statement: The authors declare that the research was conducted in the absence of any commercial or financial relationships that could be construed as a potential conflict of interest.

Copyright $\odot 2017$ Immenschuh, Vijayan, Janciauskiene and Gueler. This is an openaccess article distributed under the terms of the Creative Commons Attribution License (CC BY). The use, distribution or reproduction in other forums is permitted, provided the original author(s) or licensor are credited and that the original publication in this journal is cited, in accordance with accepted academic practice. No use, distribution or reproduction is permitted which does not comply with these terms. 